\title{
Investigating the Effectiveness of Case-based Learning Instruction on Students' Understanding the Subject of Reaction Rate*
}

\author{
Aysel Ünal SÜMEN**
}

\author{
Gülten ŞENDUR ${ }^{* * *}$
}

Received: 28 December 2013

Accepted: 20 March 2015

\begin{abstract}
This study has been carried out to determine the effectiveness of case-based learning related to reaction rate on students' conceptual understanding and conceptual change. In this respect, a class of $11^{\text {th }}$ grade students in an Anatolian High School in the center of Izmir city was chosen randomly as experimental group ( $\mathrm{n}=26)$ and another as control group $(n=22)$. Reaction rate unit was taught to the experimental group within case-based learning method, and to the control group through activities defined in Chemistry curriculum. Comprehension Test developed by Cakmakci (2005) was utilized as data collecting instrument. The Comprehension Test was applied simultaneously to both experimental and control groups before and after the teaching. The data collected via the Comprehension Test was analyzed in terms of both quantity and quality. As a result of the study, it was noted that there was a significant difference between the groups after the instruction in favor of the experimental group. Also, it was determined that case-based learning was more effective in promoting conceptual change and assuring higher level of conceptual understanding for students.
\end{abstract}

Keywords: case-based learning, conceptual change, conceptual understanding, reaction rate

\section{Extended Abstract}

Purpose and Significance: Chemistry helps people understand phenomena of everyday life (Kolomuç \& Tekin, 2011). In this context, it is important to design and apply teaching activities which allow students to integrate chemistry subjects with phenomena of everyday life. One of the methods is case-based learning. Case based learning is one of the constructivist teaching methods because students construct their knowledge with their colleagues by using real life examples (Kreber, Klampfleitner, McCune, Bayne \& Knottenbelt, 2007; Sudzina, 1997; Wellington, 2006). For this reason, it is thought that the cased-based learning may promote students' conceptual understanding. In the present study, cased-based learning was used in the unit of reaction rate which is one of the abstract subjects in chemistry. The main purpose of the study to investigate the effects of case-based learning on $11^{\text {th }}$ grade students' conceptual understanding related to reaction rate. Depending on this aim, these research questions were addressed:

- Is there any significant difference in achievement scores between pre-test of the experimental group and the control group?

- Is there any significant difference in achievement scores between post-test of the experimental group and the control group?

\footnotetext{
* This study was supported by Dokuz Eylul University Scientific Research Projects Unit (2012.KB.EGT.003).

** Teacher, Ministry of National Education, Izmir, Turkey, unalaysel@yahoo.com

*** Corresponding Author: Assist. Prof. Dr., Dokuz Eylul University, Izmir, Turkey, gulten.sendur@deu.edu.tr
} 
- How do students' conceptual understanding change after instruction?

- Do instructions used in the experimental and control groups have an effect on conceptual change?

Methods: In this study, quasi-experimental design with pre-test - post-test control group was selected. With this aim, one class was randomly assigned as the control group $(\mathrm{N}=22)$ and the other class was randomly assigned as the experimental group $(\mathrm{N}=26)$ for this study. The study was conducted with the participation of $11^{\text {th }}$ grade students in one high school in Izmir, in the first semester of the 2013-2014 academic year. Students in the control group were instructed with activities in the Chemistry curriculum, whereas students in the experimental group were taught with case-based learning. The data of this study was collected through Chemical Reactions Rate Comprehension Test (CRRCT) consisted of 9 open-ended questions. CRRCT was developed by Çakmakç1 (2005) to diagnose students' misconceptions and the level of understanding of students about reactions rate. For the reliability of the test, Cronbach alpha value was found at 0.81. The CRRCT was applied to both groups as a pre-test to identify their prior knowledge and misconceptions before the treatment. The instruction was accomplished in eight course hours in all the classes. Both of the groups were taught by the same teacher. The experimental and control groups spent equal time for studying. Before the instruction, seven cases related to reaction rate were developed by the researchers. The cases were about activation energy, fast and slow reactions, the effects of concentration, temperature, surface area and catalyst on reaction rate. Firstly, students in the experimental group were informed about the way of teaching with cases in the class. After that, students were grouped in five based on their achievement scores in chemistry exam. All groups selected one student as a reporter. Each case consisted of two sessions. In the first sessions, the cases were given to the students. It was aimed that students investigate the cases. In the second session, all of the students shared their findings to the group. Thereafter, group discussion about the cases began in the second session, the reporters presented their findings to the classroom, both cases and questions related to them were discussed. Finally, the students made a consensus about solutions related to the cases. During this process, the role of teacher was to help students analyze the cases and encourage them to share findings to classroom. After the instruction, CRRCT as a post-test was applied in all groups. For analyse statistical data, Mann Whitney $U$ test for unrelated samples was used to determine whether there was a significant difference between the experimental and control groups on pre-test and posttest scores. Also, at the pre- and post-test, the students' responses were grouped into the levels of understanding such as sound understanding, partial understanding, and percentages of students' specific misconceptions in both the pre-test and post-test were determined. The percentage difference between pre-test and post-test for each misconception was identified as the percentage of conceptual change. 
Results: Depending on first and second research questions in the study, it was determined that while there was no significant difference between at the pre-test, a significant difference was found between the groups after the instruction in favor of the experimental group. In addition, it was investigated how students' levels of understanding changed before and after instruction regarding third research question. The results of pre-test showed that the proportion of the students' responses in both the experimental and control groups fell into sound understanding were nearly equal before the instruction. On the other hand, the percentages of sound understanding category to all questions in the experimental group were higher than in the control group at posttest. Also, when the percentages of specific misconceptions were examined, it was determined that these percentages in the experimental group were less than the control group at the post-test. Another important finding was related to percentages of conceptual change. While it was identified negatively conceptual change in the control group, similar result was not determined in the experimental group.

Discussion and Conclusions: The main purpose of the present study was to investigate the effectiveness of case-based learning on $11^{\text {th }}$ grade students' conceptual understanding in the context of reaction rate. In the light of this study results, it can be said that the study contributes to literature by revealing that case-based learning instruction has a positive influence on the students' acquisition of scientific conceptions and remedying misconceptions. On the other hand, all cases in the study did not have the same effect on improving students' understanding and overcoming their misconceptions. For example, the cases about the effects of temperature and surface area on reaction rate were not very effective like the other cases. For this reason, the cases may be examined, rearranged, and their influence on students' understanding may be tested in the future studies. 


\title{
Öğrencilerin Kimyasal Tepkimelerde Hız Konusundaki Kavramsal Algılamalarında Örnek Olaya Dayalı Öğretimin Etkisinin Araştırılması*
}

\author{
Aysel Ünal SÜMEN ${ }^{* *} \quad$ Gülten ŞENDUR ${ }^{* * *}$
}

Makale Gönderme Tarihi: 28 Aralık 2013

Makale Kabul Tarihi: 20 Mart 2015

\begin{abstract}
ÖZET: Bu çalışma, kimyasal reaksiyonlarda hız konusundaki örnek olaya dayalı öğretim yönteminin öğrencilerin kavramsal algılamaları ve kavramsal değişimleri üzerindeki etkisini saptamak amacıyla yürütülmüştür. Bu amaç doğrultusunda, 2013-2014 öğretim yılı güz dönemimde İzmir il merkezindeki bir Anadolu Lisesinde 11. sınıflarda öğrenim gören iki sınıftan biri deney grubu $(n=26)$, diğeri kontrol grubu $(n=22)$ olarak rastgele seçilmiştir. Deney grubunda Kimyasal Reaksiyonlarda Hız konusu örnek olaya dayalı ögretim ile, kontrol grubunda ise Kimya öğretim programındaki etkinliklerle işlenmiştir. Çalışmada veri toplama aracı olarak Çakmakçı (2005) tarafından geliştirilmiş olan kavram testi kullanılmıştır. Kavram testi, öğretim öncesi ve sonrası deney ve kontrol gruplarına eş zamanlı olarak uygulanmıştır. Kavram testinden elde edilen veriler, hem nitel hem de nicel olarak analiz edilmiştir. Araştırma sonucunda, gruplar arasında deney grubu lehine anlamlı bir farkın olduğu ortaya çıkmıştır. Ayrıca, örnek olaya dayalı öğretimin, kavramsal değişimi sağlamada ve öğrencilerin kavramsal algılamalarının istenilen düzeylerde olmasında, daha etkili olduğu da belirlenmiştir.
\end{abstract}

Anahtar sözcükler: kavramsal algılama, kavramsal değişim, kimyasal tepkimelerde hız, örnek olaya dayalı öğretim

\section{Giriş}

Bireyler bulundukları çevredeki yaşanan olaylarla doğrudan veya dolaylı sürekli bir etkileşim içerisindedirler. Bu etkileşimin neden ve sonuçlarının incelenmesi, bunlara anlam kazandırılması bireylerin hayatlarını kolaylaştırmak adına son derece önemlidir. $\mathrm{Bu}$ süreçte fen bilimleri eğitiminin ve özellikle de kimya eğitiminin önemli bir rolü vardır. Çünkü günlük hayatımızdaki pek çok olayı açıklamada kimyadan yararlanmamız söz konusudur (Kolomuç ve Tekin, 2011). Nitekim, ortaöğretim kimya öğretim programının temel amaçlarından biri de, kimyanın gündelik hayattaki yerini kavrayan ve değerini fark eden bireyler yetiştirmek olduğu ifade edilmiştir (MEB, 2013). Bu bağlamda, öğrencilerin günlük yaşamda karşılaşabilecekleri olayları, kimya konuları ile ilişkilendirebilecekleri, onları araştırma ve sorgulamaya yönelten öğrenme-öğretme etkinliklerinin planlanması, uygulanması önem taşımaktadır. Bu yöntemlerden biri de örnek olaya dayalı öğretimdir.

Örnek olaya dayalı öğretim, öğrencilerin akranları ile birlikte, gerçek yaşam örneklerini kullanarak bilgilerini yapılandırmalarına olanak tanıyan yapısalcı yaklaşım yöntemlerinden biridir (Kreber, Klampfleitner, McCune, Bayne ve Knottenbelt, 2007; Sudzina, 1997; Wellington, 2006). Bu yöntemde, sınıfa getirilen, gerçek yaşamda karşılaşabilecek, kısa ama derinliği olan örnek olay öğrencilerce tartış1lır, analiz edilir ve bir sonuca bağlanır (Herreid, 1994; Johnson ve Purvis,1987; Wassermann, 1994).

Örnek olaya dayalı öğretimin uygulaması, öğrenci mevcuduna göre değişmekle

\footnotetext{
* Bu çalışma, Dokuz Eylül Üniversitesi Bilimsel Araştırma Projeleri Birimi (2012.KB.EGT.003) tarafından desteklenmiştir.

** Öğretmen, Milli Eğitim Bakanlığı, İzmir, unalaysel@yahoo.com

**** Sorumlu Yazar: Yrd. Doç. Dr., Dokuz Eylül Üniversitesi, İzmir, gulten.sendur@ deu.edu.tr
} 
birlikte daha çok küçük gruplar şeklinde yürütülmektedir. Bu formatta, öncelikle öğrencilere örnek olaylar verilir ve öğrencilerden verilen örnek olayla ilişkili soruları araştırmaları istenir. Bir sonraki oturumda, öğrenciler öncelikle bulgularını grup arkadaşları ile paylaşırlar, tartışırlar ve grup olarak bir sonuca ulaşırlar. Final aşamasında, tüm gruplar bulgularını sınıfa sunar, sorularla ilgili tatmin edici cevaplara ulaşıncaya kadar sınıf tartışması devam eder ve son bulur (Çam, 2009; Herreid, 1998, 2005). Bu süreçte öğretmenin rolü, gruplar örnek olaylar üzerinde çalışırken gereken rehberliği yapmak, tartışma sürecini kolaylaştırmaktır.

Örnek olaya dayalı öğretimin, fen eğitimindeki uygulamalarına sıkça rastlansa da kimya eğitiminde özellikle de kavramsal değişim üzerindeki etkilerini inceleyen çalışmalar son derece sınırlıdır. Bu çalışmalar incelendiğinde, örnek olaya dayalı öğretimin, öğrencilerin öğrenmeye yönelik istekleri, tutumları (Brink, Goodney, Hudak ve Silverstein, 1995; Cheng, 1995; Cornerley, 1998), fen bilimlerinin günlük yaşamdaki etkileri (Jones, 1997), akademik başarıları (Cheng, 1995; Çam, 2009; Şendur, 2011), kimyaya yönelik tutumları (Çam ve Geban, 2011), motivasyonları (Yalçınkaya, Boz ve Erdur-Baker, 2012) üzerinde olumlu etkileri olduğu belirlenmiştir. Bunların yanında, Taştan-Kırık, Boz ve Yıldıran (2012), Ayyıldız ve Tarhan (2013), Yalçınkaya ve Boz (2014) tarafından yürütülen araştırma sonuçlarından da örnek olaya dayalı öğretimin, öğrencilerde kavram yanılgılarının giderilmesinde ve kavramsal değişimin sağlanmasında etkili olduğu ortaya çıkmıştır.

Alanyazındaki bu çalışmalara bağlı olarak, kimyanın temel kavram ve ilkelerinin, günlük yaşam ile ilişkilendirildiği örnek olaya dayalı öğretim uygulamalarının geliştirilmesinin, bu öğretimin öğrencilerin kavramsal algılamaları ve kavramsal değişim üzerindeki etkisinin incelenmesinin önemli olduğu düşünülmektedir.

$\mathrm{Bu}$ nedenle, bu çalışmada kimyanın en temel ve soyut konularından biri olan kimyasal tepkimelerde hız konusunda örnek olaya dayalı öğretimin, öğrencilerin kavramsal algılamaları üzerindeki etkisi incelenmiştir.

Kimyasal tepkimelerde hız konusu ile ilgili yürütülen çalışmalar, ortaöğretimden üniversiteye kadar farklı seviyelerdeki öğrencilerde (Çakmakçı, Leach ve Donnelly 2006; Çakmakçı, 2010; Garnett, Garnett ve Hackling, 1995; Nakipoğlu, Benlikaya ve Kalın, 2002), öğretmen adaylarında (Taştan-Kırık, Yalçınkaya ve Boz, 2010) ve hatta öğretmenlerde (Kolomuç ve Tekin, 2011; Kolomuç ve Çalık, 2012) dahi bu konuda kavram yanılgılarının mevcut olduğunu göstermektedir. $\mathrm{Bu}$ bulgular, kimyasal tepkimelerde hız konusunun kavramsal algılamasında, öğretmen, öğretmen adayı ve öğrencilerin zorluk çektiklerini göstermektedir. Bu nedenle, kimyasal tepkimelerde hız konusundaki temel kavram ve ilkeleri, günlük yaşamla ilişkilendirmeyi kolaylaştıracak, öğrenci merkezli alternatif öğretim yöntemlerinin uygulanması son derece önemli görülmektedir.

$\mathrm{Bu}$ araştırmayla da, 11. sınıf öğrencilerinin kimyasal tepkimelerde hız konusundaki kavramsal algılamalarında alternatif öğretim yöntemlerinden biri olan örnek olaya dayalı öğretimin etkisinin ne olduğunun ortaya çıkartılması amaçlanmıştır. $\mathrm{Bu}$ amaç doğrultusunda, araştırmada şu alt problemlere cevap aranmıştır: 
- Örnek olaya dayalı öğretimin uygulandığı deney grubu öğrencileri ile Kimya öğretim programındaki etkinlikleri temel alan öğretimin uygulandığı kontrol grubu öğrencilerin kavram ön-testinden aldıkları puanlar arasında anlamlı bir fark var midir?

- Örnek olaya dayalı öğretimin uygulandığı deney grubu öğrencileri ile Kimya öğretim programındaki etkinlikleri temel alan öğretimin uygulandığ grubu öğrencilerin kavram son-testinden aldıkları puanlar arasında anlamlı bir fark var midır?

- Deney ve kontrol grubu öğrencilerinin kavramsal algılamaları öğretim sonrası ne gibi değişiklikler göstermektedir?

- Deney ve kontrol gruplarında uygulanan öğretim yöntemlerinin kavramsal değişimin sağlanmasında bir etkisi var mıdır?

\section{Yöntem}

\section{Araştırmanın Modeli}

Araştırmanın amacı doğrultusunda oluşturulan alt problemlere yanıt bulabilmek için öntest-sontest kontrol gruplu yarı deneysel model kullanılmıştır. Araştırmada, deney ve kontrol gruplarına, öğrencilerin rastgele atanma durumları olmadığı için yarı deneysel modelin kullanılmasına karar verilmiştir (Cohen, Manion ve Morrison, 2007; Çepni, 2010). Bu modele göre, deneysel işleme geçilmeden önce yansız olarak seçilen deney ve kontrol gruplarında eş zamanlı olarak ön-testler uygulanmıştır. Deney grubunda " kimyasal reaksiyonlarda hız" konusu örnek olaya dayalı anlatılırken, kontrol grubunda ise Kimya öğretim programındaki etkinlikler doğrultusunda işlenmiştir. Deneysel işlemin sona ermesinden sonra, deney ve kontrol gruplarında son-testler uygulanmıştır.

\section{Çalışma Grubu}

Araştırmanın çalışma grubunu, MEB'den izin alınan İzmir il merkezindeki bir Anadolu Lisesinden seçilen iki sınıfta (bir deney, bir kontrol grubu) öğrenim gören 48, 11. sınıf öğrencisi oluşturmuştur. Araştırmada, deney grubunda 26, kontrol grubunda 22 öğrenci bulunmaktadır.

\section{Veri Toplama Araci}

Öğrencilerin ön bilgilerini ve varsa kavram yanılgılarını belirlemek, ünitenin öğretiminden sonra öğrencilerin kavramsal algılamalarındaki değişimi tespit etmek amacıyla, Çakmakçı'nın (2005) geliştirdiğgi, Kolomuç (2009) tarafından Türkçeye çevrilen "kimyasal tepkimelerde hız kavram testi" kullanılmıştır. Test, ünitenin içeriğinin tamamımı içermesi ve kavram yanılgılarını ayrıntılı bir şekilde inceleme firsatı verebilecek açık uçlu sorulardan oluşması nedeniyle seçilmiştir. Test, 9 açık uçlu sorudan oluşmuş olup, testin Cronbach Alfa güvenirlik değeri Kolomuç tarafından 0.81 olarak bulunmuştur. 


\section{Deneysel İşlem}

Uygulama, 2013-2014 öğretim y1lı güz dönemimde gerçekleştirilmiştir. Deney ve kontrol gruplarında eş zamanlı olarak ön-testlerin uygulanmasının ardından dersler deney grubunda örnek olaya dayalı öğretimle, kontrol grubunda ise Kimya öğretim programındaki etkinlikler temel alınarak işlenmiştir. Deney ve kontrol gruplarında dersler 8 ders saatinde (haftada 2 saat) tamamlanmış olup, her iki grubun dersleri aynı öğretmen tarafından yürütülmüştür.

Kontrol grubunda, derslerin işlenmesi sürecinde Kimya öğretim programındaki etkinlikler temel alınırken, öğretmen konu ile ilgili genel kavram ve ilkeleri açıkladıktan sonra, öğrencilerin problem çözme ve soru-cevap teknikleri ile aktif hale getirilmesi sağlanmıştır.

Deney grubunda ise örnek olaya dayalı öğretim temel alındığı için öncelikle, konu ile ilgili 7 örnek olay geliştirilmiştir. Örnek olaylar çeşitli kitap ve makalelerden yararlanılarak ve uzman görüşüne başvurularak geliştirilmiştir (Didari,1986; Payan ve Ertürk, 2002; Wertheim, Oxlade, ve Stockley 2011). Örnek olaylar geliştirilirken, öğrencilerin bildikleri ya da karşılaşabilecekleri durumları içermesine dikkat edilmiştir. Böylelikle, geliştirilen örnek olayların öğrencilerin empati yeteneğini geliştirmesi ve var olan durum üzerinde istekli olarak çalışmalarını sağlaması amaçlanmıştır (Herreid, 1998).

Geliştirilen örnek olayların pilot çalışması, 2012-2013 öğretim y1lı ikinci döneminde, İzmir il merkezindeki bir ortaöğretim kurumunda 21 kişiden oluşmuş bir gruba uygulanmıştır. Uygulama sonunda akademik başarılarına göre, üst, orta ve alt gruptan 3'er, toplamda 9 öğrenci ile görüşme yapılmıştır. Görüşmelerde, öğrencilerin örnek olaylarla ilgili anlamadıkları ya da eksik gördükleri noktalar belirlenmiş ve bunların 1şığında örnek olaylara son şekli verilmiştir. Geliştirilen örnek olaylar ve ilişkili oldukları konular Tablo 1'de gösterilmiştir.

Tablo 1

Araştırmada Geliştirilen Örnek Olaylar ve Konu Iç̧eriği

\begin{tabular}{ll}
\hline Örnek Olay Adı & İlişkili Olduğu Konu \\
\hline Tren Raylarına Ne Oldu? & Hızlı ve Yavaş Reaksiyonlar \\
Yangın Nasıl Çıktı? & Aktivasyon Enerjisi \\
Işık Çubukları & Reaksiyon Hızı- Sıcaklık İlişkisi \\
Organ Nakli & Reaksiyon Hızı- Sıcaklık İlişkisi \\
Heykellere Neler Oluyor? & Reaksiyon Hızı- Derişim İlişsisi \\
Kömür Madenlerindeki Patlamalar & Reaksiyon Hızı -Temas Yüzeyi İlişkisi \\
Katalitik Konvektörler & Reaksiyon Hızı- Katalizör İlişsisi \\
\hline
\end{tabular}

Araştırmada geliştirilen örnek olaylardan biri Şekil 1'de gösterilmiştir. 
Şekil 1. Araştırmada Geliştirilen Örnek Olaylardan Bir Örnek

KÖMÜR MADENLERINDEKI PATLAMALAR
Metan gazı ve hava karışımına grizu denir. Kömür madenlerinde genellikle grizu patlaması
meydana gelir. Metan gazının oranı $\% 5-9,5$ arasında olduğunda patlama olur. Çin'in kuzeydoğusundaki
Cilin eyaletinde bir kömür madeninde meydana gelen patlamada 28 işçinin öldüğü bildirilmiştir. Yapılan
açıklamada:
Metan gazının patlamaya neden olacak seviyede olmadığı, kömür madeninde bulunan kömür
tozu havaya kalkmış halde bulunursa, madenlerdeki elektrik hattındaki akımla bile reaksiyona girerek
patlamaya neden olabileceği belirtilmiştir.
Öncelikle verilen metni okuduktan sonra, așağıdaki soruları cevaplavınız
1) Maden kazası ile ilgili haber duydunuz mu?
2) Sizce madenlerdeki kömür tozunun havaya kalkmaması için ne gibi önlemler alınabilir?
3) İri bir parça kömür elektrik hattındaki akımla reaksiyona girmezken, kömür tozunun
reaksiyona girmesini nasıl açıklarsınız?
4) Acaba reaksiyonlarda kömür tozunun boyutu önemli midir?
5) Reaksiyon hızıyla tanecik boyutu arasında bir ilişki var mıdır? Nasıl bir ilişki vardır?

Deney grubu öğrencilerine, öğretim öncesinde örnek olaya dayalı öğretimin nasıl uygulanacağı hakkında bilgi verilmiş ve bunun ardından dersin işlenişine geçilmiştir. Öğrenciler akademik başarıları dikkate alınarak beşer kişilik (4 grup) ve altışar kişilik (1 grup) gruplara ayrılmış ve her grupta yüksek, orta ve düşük başarı düzeyine sahip öğrencilerin eşit sayıda olmasına dikkat edilmiştir. Her gruptan bir sözcü seçilmiştir. Örnek olaylar, iki oturum halinde ele alınmıştır. İlk oturumda, öğrencilere örnek olaylar dağıtılmış, örnek olaylar üzerinde tartışmaları ve ilgili soruları araştırmaları sağlanmıştır. Íkinci oturumda ise, grup üyelerinin bulgularını birbiriyle paylaşmaları ve ortak bir sonuca ulaşmaları sağlanmıştır. Daha sonra grup sözcülerinin, örnek olaylara verdikleri cevapları sınıfa sunmaları ile genel bir değerlendirme yapılmıştır. Bu süreçte ders öğretmeninin görevi, öğrencilerin örnek olayları analiz etmelerine yardımcı olmak ve onları, bulgularını sınıfla paylaşmaya cesaretlendirmektir. Deney ve kontrol grubunda sekiz ders saatinde kimyasal tepkimelerde hiz konusunun işlenmesinin ardından eş zamanlı olarak son-test olan kavram testi uygulanmıştır.

\section{Verilerin Analizi}

Literatürdeki pek çok çalışmada, öğrencilerin anlama seviyelerini değerlendirmek için açık uçlu sorulardan elde edilen verilerin daha düzenli ve organize halde sunulmasının, kategorilerin kullanılmasıyla mümkün olacağı ifade edilmiştir (Abraham, Grzybowski, Renner ve Marek, 1992; Çalık, 2005; Ünal, Coştu ve Ayas, 2010) Bu nedenle, bu çalışmada açık uçlu sorulardan elde edilen verilerin analizinde da, yukarıda belirtilen araştırmalarda da kullanılan tam anlama (4 puan), kısmi anlama (3 puan), spesifik kavram yanılgılı kısmi anlama (2 puan), spesifik kavram yanılgısı (1 puan) ve anlamama (0 puan) kategorileri kullanılmıştır. Kategorilerin içeriği, Tablo 2'de sunulmuştur. 
Tablo 2

Kavram Testinde Yer Alan açık Uçlu Soruları Analiz Etmede Kullanılan Kategoriler ve Içerikleri

\begin{tabular}{|c|c|c|}
\hline Anlama Düzeyleri & Puan & Puanlama Kriteri \\
\hline Tam Anlama (TA) & 4 & Geçerliliği olan cevabın bütün yönlerini içeren cevaplar \\
\hline Kismi Anlama (KA) & 3 & $\begin{array}{l}\text { Geçerli olan cevabın bir yönünü içeren fakat bütün yönlerini } \\
\text { içermeyen cevaplar }\end{array}$ \\
\hline $\begin{array}{l}\text { Spesifik Kavram Yanılgılı } \\
\text { Kısmi Anlama(SKYKA) }\end{array}$ & 2 & $\begin{array}{l}\text { Kavramın kısmen anlaşıldığını gösteren fakat aynı zamanda bir } \\
\text { alternatif kavramı da içeren cevaplar }\end{array}$ \\
\hline $\begin{array}{l}\text { Spesifik Kavram Yanılgısı } \\
(\text { SKY) }\end{array}$ & 1 & Bilimsel olarak yanlış olan cevaplar \\
\hline Anlamama (Anl.) & 0 & $\begin{array}{l}\text { Boş bırakma, bilmiyorum, anlamadım şeklindeki cevaplar, } \\
\text { soruyu aynen tekrarlama, ilgisiz ya da açık olmayan cevaplar }\end{array}$ \\
\hline
\end{tabular}

Verilerin istatistiksel analizinde, SPSS 13.0 paket programından yararlanılmıştır. Verilerin normal dağılım göstermediği durumlarda non-parametrik testin kullanılması önerilmektedir (Özdamar, 2004). Bu nedenle, deney ve kontrol gruplarının ön ve sontest puanları, parametrik olmayan testlerden olan bağımsız örneklemler için Mann Whitney $U$ testi kullanılarak karşılaştırılmıştır. Ayrıca, deney ve kontrol grubu öğrencilerinin ön ve son-testteki cevaplarının kategorilere göre dağılımı, frekans ve yüzde olarak tablolarda gösterilmiştir. Bunlara ilaveten, deney ve kontrol gruplarındaki kavramsal değişimin karşılaştırılabilmesi amacıyla kavram yanılgılarının yüzdeleri saptanmış ve bu yanılgıların ön ve son-testlerdeki yüzdeleri arasındaki fark, kavramsal değişimin yüzdesi (KD) olarak belirtilmiştir.

\section{Bulgular}

Yürütülen bu araştırma ile 11. sınıf öğrencilerinin kimyasal tepkimelerde hız konusundaki kavramsal algılamalarında, örnek olaya dayalı öğretimin etkisinin ne olduğunun ortaya çıkarılması hedeflenmiştir. $\mathrm{Bu}$ doğrultuda belirlenen alt problemlerden biri de "örnek olaya dayalı öğretimin uygulandığı deney grubu öğrencileri ile Kimya öğretim programındaki etkinlikleri temel alan öğretimin uygulandığı kontrol grubu öğrencilerin kavram ön-testinden aldıkları puanlar arasında anlamlı bir fark var mıdır?” sorusudur. Bu amaçla deney ve kontrol grubu öğrencilerinin ön-test kavram testinden aldıkları puanlar Mann Whitney U testi ile karşılaştırılmıştır. Ön-test kavram testine ilişkin Mann Whitney U testi analiz sonuçları Tablo 3'te verilmiştir. 
Tablo 3

Deney ve Kontrol Gruplarının Ön-Test Puanlarına İlişkin M-W U Testi Sonuçları

\begin{tabular}{cccccc}
\hline Gruplar & $n$ & $\begin{array}{c}\text { Sira } \\
\text { Ortalamas }\end{array}$ & $\begin{array}{c}\text { Sira } \\
\text { Toplamı }\end{array}$ & $U$ & $p$ \\
Deney & 26 & 24.63 & 640.50 & 282.500 & $.942 *$ \\
Kontrol & 22 & 24.34 & 535.50 & & \\
\hline
\end{tabular}

Tablo 3 incelendiğinde, deney ve kontrol grubu öğrencilerinin ön-test kavram testinden aldıkları puanlar arasında istatistiksel olarak anlamlı bir farkın olmadığ anlaşılmaktadır ( $U=282.500, p>.05)$. Bu durum, deney ve kontrol gruplarının uygulama öncesi sıra ortalamalarının birbirine yakın olduğunu göstermektedir.

Araştırmanın bir diğer alt problemi olan "Örnek olaya dayalı öğretimin uygulandığı deney grubu öğrencileri ile Kimya öğretim programındaki etkinlikleri temel alan öğretimin uygulandığ puanlar arasında anlamlı bir fark var mıdır?" sorusuna cevap aramak için Mann Whitney $U$ testi kullanılmıştır. Son-test kavram testine ilişkin Mann Whitney U testi analiz sonuçlarına Tablo 4'te yer verilmiştir.

Tablo 4

Deney ve Kontrol Gruplarının Son-Test Puanlarına İlişkin M-W U Testi Sonuçları

\begin{tabular}{lccccc}
\hline Gruplar & $N$ & $\begin{array}{c}\text { Sira } \\
\text { Ortalaması }\end{array}$ & $\begin{array}{c}\text { Sira } \\
\text { Toplamı }\end{array}$ & $U$ & $P$ \\
\hline Deney & 26 & 30.83 & 801.50 & 121.500 & .001 \\
Kontrol & 22 & 17.02 & 374.50 & \\
\hline
\end{tabular}

Tablo 4, deney ve kontrol grubu öğrencilerinin son-test kavram testinden aldıkları puanlar arasında istatistiksel olarak anlamlı bir farkın olduğunu göstermektedir $(U=121.500, p<.05)$. Analiz sonucunda, deney ve kontrol gruplarının uygulama sonras1 sıra ortalamaları karşılaştırıldığında deney grubu lehine anlamlı bir farkın olduğu saptanmıştır. Bu durum, ön-testlerde aralarında anlamlı fark olmayan bu iki gruptan, deney grubu öğrencilerinin; deneysel uygulama sonrasında kontrol grubu öğrencilerine göre kavramsal gelişimlerinin daha yüksek olduğunu göstermektedir.

Araştırmanın üçüncü alt problemi olan "Deney ve kontrol grubu öğrencilerinin kavramsal algılamaları öğretim sonrası ne gibi değişiklikler göstermektedir?” sorusunu cevaplamak için, öğrencilerin ön ve son-testte verdikleri cevapların kategorilere göre dağılımı hesaplanmış ve bunlar Tablo 5 ve Tablo 6' da gösterilmiştir. 
Tablo 5

Deney ve Kontrol Grubu Öğrencilerinin Ön-Test Kavram Testine Verdikleri Cevapların Kategorilere Göre Dă̆ılımı

\begin{tabular}{|c|c|c|c|c|c|c|c|c|c|c|c|c|c|c|c|c|c|c|c|c|}
\hline \multirow{3}{*}{ 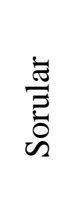 } & \multicolumn{10}{|c|}{ DENEY GRUBU } & \multicolumn{10}{|c|}{ KONTROL GRUBU } \\
\hline & \multicolumn{2}{|c|}{ TA } & \multicolumn{2}{|c|}{$\mathrm{KA}$} & \multicolumn{2}{|c|}{ SKYKA } & \multicolumn{2}{|c|}{ SKY } & \multicolumn{2}{|c|}{ Anl. } & \multicolumn{2}{|c|}{$\mathrm{TA}$} & \multicolumn{2}{|c|}{$\mathrm{KA}$} & \multicolumn{2}{|c|}{ SKYKA } & \multicolumn{2}{|c|}{ SKY } & \multicolumn{2}{|c|}{ Anl. } \\
\hline & $f$ & $\%$ & $f$ & $\%$ & $f$ & $\%$ & $f$ & $\%$ & $f$ & $\%$ & $f$ & $\%$ & $f$ & $\%$ & $f$ & $\%$ & $f$ & $\%$ & $f$ & $\%$ \\
\hline $1-\mathrm{a}$ & 2 & 8 & 6 & 23 & 3 & 12 & 10 & 38 & 5 & 19 & 4 & 18 & 4 & 18 & 1 & 5 & 9 & 41 & 4 & 18 \\
\hline $1-b$ & - & - & 4 & 15 & 3 & 12 & 14 & 54 & 5 & 19 & - & - & 3 & 14 & - & - & 14 & 65 & 5 & 23 \\
\hline 2 & 3 & 12 & 9 & 35 & 1 & 4 & 2 & 8 & 11 & 42 & 1 & 5 & 11 & 50 & - & - & 4 & 18 & 6 & 27 \\
\hline $3-a$ & 9 & 35 & 4 & 15 & 2 & 8 & - & - & 11 & 42 & 13 & 59 & 4 & 18 & - & - & 1 & 5 & 4 & 18 \\
\hline $3-b$ & - & - & 6 & 23 & 1 & 4 & 15 & 58 & 4 & 15 & - & - & 6 & 27 & 1 & 5 & 10 & 45 & 5 & 23 \\
\hline $3-c$ & - & - & 15 & 58 & 1 & 4 & 7 & 27 & 3 & 12 & - & - & 9 & 41 & 2 & 9 & 6 & 27 & 5 & 23 \\
\hline $3-d$ & - & - & 1 & 4 & - & - & 22 & 85 & 3 & 12 & - & - & 2 & 9 & - & - & 15 & 68 & 5 & 23 \\
\hline $4-a$ & 1 & 4 & - & - & - & - & 22 & 85 & 3 & 12 & 2 & 9 & - & - & - & - & 17 & 77 & 3 & 14 \\
\hline $4-b$ & - & - & 1 & 4 & 3 & 12 & 13 & 50 & 9 & 35 & 1 & 5 & - & - & 4 & 18 & 9 & 41 & 8 & 36 \\
\hline $5-a$ & 2 & 8 & 6 & 23 & 3 & 12 & 10 & 38 & 5 & 19 & 3 & 14 & 5 & 23 & - & - & 10 & 45 & 4 & 18 \\
\hline $5-b$ & 1 & 4 & 2 & 8 & 3 & 12 & 10 & 38 & 10 & 38 & 1 & 5 & - & - & 1 & 5 & 6 & 27 & 14 & 65 \\
\hline 6 & 3 & 12 & - & - & - & - & 21 & 81 & 2 & 8 & 4 & 18 & - & - & - & - & 13 & 59 & 5 & 23 \\
\hline $7-a$ & 19 & 73 & 1 & 4 & - & - & 3 & 12 & 3 & 12 & 13 & 59 & - & - & - & - & 4 & 18 & 5 & 23 \\
\hline $7-b$ & 17 & 65 & 1 & 4 & 1 & 4 & 4 & 15 & 3 & 12 & 11 & 50 & - & - & - & - & 3 & 14 & 8 & 36 \\
\hline $8-a$ & 13 & 50 & - & - & - & - & 11 & 42 & 2 & 8 & 9 & 41 & - & - & - & - & 7 & 32 & 6 & 27 \\
\hline $8-b$ & 8 & 31 & 2 & 8 & 1 & 4 & 14 & 54 & 2 & 8 & 6 & 27 & 1 & 5 & - & - & 10 & 45 & 5 & 23 \\
\hline $9 \mathrm{a}_{1}$ & 2 & 8 & 18 & 69 & - & - & 4 & 15 & 2 & 8 & 1 & 5 & 15 & 68 & 2 & 9 & 1 & 5 & 3 & 14 \\
\hline $9 \mathrm{a}_{2}$ & 2 & 8 & 11 & 42 & 2 & 8 & 8 & 31 & 3 & 12 & 3 & 14 & 4 & 18 & - & - & 11 & 50 & 4 & 18 \\
\hline $9 \mathrm{a}_{3}$ & 1 & 4 & 11 & 42 & 1 & 4 & 11 & 42 & 2 & 8 & 3 & 14 & 13 & 59 & - & - & 3 & 14 & 3 & 14 \\
\hline $9 \mathrm{a}_{4}$ & - & - & 7 & 27 & 1 & 4 & 14 & 54 & 4 & 15 & 2 & 9 & 3 & 14 & - & - & 13 & 59 & 4 & 18 \\
\hline $9-b$ & 1 & 4 & - & - & - & - & 19 & 73 & 6 & 23 & - & - & - & - & - & - & 17 & 77 & 5 & 23 \\
\hline 9-c & - & - & 1 & 4 & 1 & 4 & - & - & 24 & 92 & - & - & 2 & 9 & - & - & 2 & 9 & 18 & 82 \\
\hline
\end{tabular}

*TA: Tam Anlama, KA: Kısmi Anlama, SKYKA: Spesifik Kavram Yanılgılı Kısmi Anlama, SKY: Spesifik Kavram Yanılgisı, Anl: Anlamama 
Tablo 6

Deney ve Kontrol Grubu Ögrencilerinin Son-Test Kavram Testine Verdikleri Cevapların Kategorilere Göre Dă̆ılımı

\begin{tabular}{|c|c|c|c|c|c|c|c|c|c|c|c|c|c|c|c|c|c|c|c|c|}
\hline \multirow{3}{*}{ 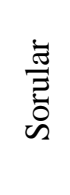 } & \multicolumn{9}{|c|}{ DENEY GRUBU } & \multicolumn{11}{|c|}{ KONTROL GRUBU } \\
\hline & \multicolumn{2}{|l|}{ TA } & \multicolumn{2}{|l|}{ KA } & \multicolumn{2}{|c|}{ SKYKA } & \multicolumn{2}{|c|}{ SKY } & \multicolumn{2}{|c|}{ Anl. } & \multicolumn{2}{|c|}{$\mathrm{TA}$} & \multicolumn{2}{|c|}{ KA } & \multicolumn{2}{|c|}{ SKYKA } & \multicolumn{2}{|c|}{ SKY } & \multicolumn{2}{|c|}{ Anl. } \\
\hline & $f$ & $\%$ & $f$ & $\%$ & $f$ & $\%$ & $f$ & $\%$ & $f$ & $\%$ & $f$ & $\%$ & $f$ & $\%$ & $f$ & $\%$ & $f$ & $\%$ & $f$ & $\%$ \\
\hline $1-\mathrm{a}$ & 23 & 88 & 1 & 4 & - & - & 2 & 8 & - & - & 18 & 82 & - & - & - & - & 2 & 9 & 2 & 9 \\
\hline $1-b$ & 4 & 15 & 20 & 77 & - & - & 2 & 8 & - & - & 2 & 9 & 17 & 77 & - & 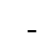 & 2 & 9 & 1 & 5 \\
\hline 2 & 17 & 66 & 8 & 31 & - & - & - & - & 1 & 4 & 3 & 14 & 16 & 73 & - & - & 1 & 5 & 2 & 9 \\
\hline $3-\mathrm{a}$ & 21 & 81 & - & - & - & - & - & - & 5 & 19 & 17 & 77 & - & - & - & - & - & - & 5 & 23 \\
\hline $3-b$ & 20 & 77 & 5 & 19 & - & - & - & - & 1 & 4 & 9 & 41 & 10 & 45 & - & - & 1 & 5 & 2 & 9 \\
\hline $3-\mathrm{c}$ & 7 & 27 & 17 & 66 & - & - & 2 & 8 & - & - & 3 & 14 & 15 & 68 & - & - & 2 & 9 & 2 & 9 \\
\hline $3-d$ & 6 & 23 & 15 & 58 & - & - & 2 & 8 & 3 & 12 & 2 & 9 & 6 & 27 & - & - & 11 & 50 & 3 & 14 \\
\hline 4-a & 22 & 85 & - & - & - & - & 3 & 12 & 2 & 8 & 13 & 59 & - & - & - & - & 7 & 32 & 2 & 9 \\
\hline 4-b & 10 & 38 & 8 & 31 & - & - & - & - & 8 & 31 & 2 & 9 & 10 & 45 & - & - & 4 & 18 & 6 & 27 \\
\hline $5-a$ & 15 & 58 & 5 & 19 & 3 & 12 & - & - & 3 & 12 & 7 & 32 & 10 & 45 & - & - & 1 & 5 & 4 & 18 \\
\hline 5-b & 8 & 31 & 6 & 23 & - & - & 5 & 19 & 7 & 27 & 2 & 9 & 10 & 45 & - & - & 4 & 18 & 6 & 27 \\
\hline 6 & 9 & 35 & 1 & 4 & - & - & 14 & 54 & 2 & 8 & 1 & 5 & 4 & 18 & - & - & 13 & 59 & 4 & 18 \\
\hline $7-a$ & 21 & 81 & - & - & - & - & 3 & 12 & 2 & 8 & 16 & 73 & - & - & - & - & 4 & 18 & 2 & 9 \\
\hline 7-b & 21 & 81 & - & - & - & - & 1 & 4 & 4 & 15 & 15 & 68 & 3 & 14 & - & - & 1 & 5 & 3 & 14 \\
\hline $8-a$ & 21 & 81 & - & - & - & - & 3 & 12 & 2 & 8 & 16 & 73 & - & - & - & - & 4 & 18 & 2 & 9 \\
\hline 8-b & 18 & 69 & 6 & 23 & 1 & 4 & - & - & 1 & 4 & 4 & 18 & 3 & 14 & - & - & 11 & 50 & 4 & 18 \\
\hline $9 a_{1}$ & 19 & 73 & 6 & 23 & - & - & - & - & 1 & 4 & 4 & 18 & 17 & 77 & - & - & - & - & 1 & 5 \\
\hline $9 a_{2}$ & 19 & 73 & 5 & 19 & - & - & - & - & 2 & 8 & 4 & 18 & 13 & 59 & - & - & 4 & 18 & 1 & 5 \\
\hline $9 a_{3}$ & 5 & 19 & 20 & 77 & - & - & 1 & 4 & - & - & 3 & 14 & 13 & 59 & - & - & 5 & 23 & 1 & 5 \\
\hline $9 a_{4}$ & 8 & 31 & 16 & 62 & - & - & 2 & 8 & - & - & - & - & 15 & 68 & - & - & 5 & 23 & 2 & 9 \\
\hline 9-b & 16 & 62 & - & - & - & - & 7 & 27 & 3 & 12 & 5 & 23 & - & - & - & - & 12 & 55 & 5 & 23 \\
\hline 9-c & 2 & 8 & 12 & 46 & - & - & - & - & 12 & 46 & - & - & 9 & 41 & - & - & - & - & 13 & 59 \\
\hline
\end{tabular}

Öğrencilerin reaksiyon hızını tanımlamalarının istendiği 1 . sorunun a alt maddesinde, "Birim zamanda harcanan madde miktarıdır.", "Belirli zaman aralığında girenlerin ürünlere dönüşme miktarıdır.", "Belli zaman aralığında ürünlerin oluşma miktarıdır." ifadeleri TA kategorisinde yer almış olup, ön-testte deney grubu öğrencilerinin $\% 8$ 'i, kontrol grubu öğrencilerinin $\% 18$ 'i bu kategoride yer almıştır. Sontestte ise deney grubu öğrencilerinin \%88'i, kontrol grubu öğrencilerinin \%82'si bu kategoriye giren cevapları vermişlerdir. KA kategorisinde ise "reaksiyon hızını sadece ürünlerin oluşma hızı" olarak açıklayan ifadeler yer almakta olup, ön-testte deney grubu 
öğrencilerinin \%23'ünün, kontrol grubu öğrencilerinin ise \%18'inin cevapları bu kategoride yer almıştır. Son-testte ise deney grubu öğrencilerinin \% 4'ü bu kategoriye giren cevapları verirken, kontrol grubu öğrencilerinde bu kategoriye rastlanmamıştır. SKYKA kategorisinde ise "Tepkime hızı sadece ürünlerin oluşma hızıdır ve zamanla hız artar." ifadesi yer almaktadır. Ön-testte deney grubu öğrencilerinin \%12'si, kontrol grubu öğrencilerinin \%5'i bu kategoride yer alan cevapları verirken, son-testte her iki grupta da bu kategoriye giren cevaplar yer almamıştır. "Reaksiyon hızı, reaksiyonun gerçekleşmesi için gereken süredir." veya "Reaksiyon hızı, tepkime sonunda madde oluşmasıdır." ifadeleri SKY kategorisinde yer almıştır. Ön-testte deney grubu öğrencilerinin \%38'i, kontrol grubu öğrencilerinin \%41'i bu kategoride yer alırken, sontestte bu oran deney grubunda $\% 8$, kontrol grubunda ise \%9'a düşmüştür.

Reaksiyon hızının başlangıçtan bitiş anına kadar nasıl bir değişim gösterdiğinin sorulduğu 1. sorunun $b$ alt maddesinde "Reaksiyon hızı başlangıçta hızlıdır, zamanla çarpışan tanecik sayısı azalacağı için tepkime hızı da yavaşlar." ifadesi TA kategorisinde kabul edilmiştir. Deney ve kontrol gruplarında ön-testte bu kategoride yer alan öğrenci olmazken, son-testte ise deney grubu öğrencilerinin \%15'i, kontrol grubu öğrencilerinin \%9'u TA kategorisinde yer almıştır. KA kategorisinde ise "Hız sürekli azalır." ve "Derişim azaldığı için hız azalır." ifadeleri yer almaktadır. Bu kategoride öntestte deney grubu öğrencilerinin $\% 15$ ' $i$, kontrol grubu öğrencilerinin $\% 14$ 'ü, son-testte ise deney ve kontrol grubu öğrencilerinin \%77'si bulunmaktadır. SKYKA kategorisinde "Reaksiyon hızı girenlerin miktarına bağlıdır ve değişme olmaz.", "Reaksiyon başladığında hızlıdır daha sonra giren miktarı azaldıkça hız biraz azalır ve sabit kalır." ifadeleri yer almaktadır. Ön-testte deney grubu öğrencilerinin \%12'si bu kategoride yer alırken, kontrol grubu öğrencilerinden bu kategoriye giren cevap veren olmamıştır. Sontestte ise her iki grupta da bu kategoride bir cevaba rastlanmamıştır. Öğrencilerin verdikleri cevaplardan "Reaksiyon hızı, zamanla artar.", "Reaksiyon hızı, önce artar sonra azalır." "Reaksiyon hızı, reaksiyon süresince sabittir." ve "Çevresel faktörlere göre hız farklılık gösterir.” ifadeleri SKY kategorisinde yer alan cevaplardır. Deney grubu öğrencilerinin \%54'ü, kontrol grubu öğrencilerinin \%65'i ön-testte bu kategoride yer alan cevapları verirken, son-testte her iki grupta da bu oran düşmüş, deney grubunda $\% 8$, kontrol grubunda $\% 9$ olmuştur.

Aynı zaman aralığında sıcak su musluğunun soğuk su musluğuna göre neden daha fazla paslandığının sorulduğu 2. soruda, TA kategorisinde; "Sıcaklık arttıkça, çarpışma sayısının artmasına bağlı olarak reaksiyonun hızlanacağı ve buna bağlı olarak sıcak su musluğunun birim zamanda daha fazla paslanacağı." ifadesi yer almaktadır. Ön- testte, deney grubu öğrencilerinin \%12'si, kontrol grubu öğrencilerinin ise \%5'i bu kategoriye giren cevap verebilmiştir. Son-testte ise bu oran deney grubunda \% 66'ya çıkarken, kontrol grubunda ise \%14 olmuştur. KA kategorisinde ise öğrenciler, sıcaklığın tepkime hızını arttırdığını ifade etmiş ancak bunu açıklarken, çarpışma sayısının artışından bahsetmemişlerdir. "Sıcaklık reaksiyon hızını artırır." ve "Sicaklık paslanma tepkimesini hızlandırır." ifadeleri KA kategorisinde yer alan ifadelerdir. Öntestte deney grubu öğrencilerinin \%35'i, kontrol grubu öğrencilerinin \%50’si bu 
kategoriye giren cevapları verirken, son-testte bu oran deney grubunda \%31'e düşerken, kontrol grubunda \%73'ye çıkmıştır. SKYKA kategorisinde ise "Paslanma için 1s1 gereklidir, 1Sı arttıkça daha hızlı paslanma olur." ifadesi yer almıştır. Ön-testte, bu kategoriye sadece deney grubu öğrencilerinin \% 4'ü girerken, son-testte hem deney hem de kontrol grubu öğrencilerinde bu kategoriye rastlanmamıştır. SKY kategorisinde "Sıcak su içinde pas daha çoktur.", "Sıcak su saf değildir, içindeki maddeler farklıdır." ve "Musluk içindeki madde, sıcak suyla daha fazla çözünür." ifadeleri yer almıştır. Öntestte deney grubu öğrencilerinin \%8'i, kontrol grubu öğrencilerinin ise \%18'i bu kategoriye giren cevapları verirken, son-testte sadece kontrol grubu öğrencilerinin $\% 5$ 'inde bu kategoriye rastlanmıştır.

3. sorunun a alt maddesinde ise öğrencilerden, ayrışma tepkimesi verilen NO gazının derişim-zaman grafiğini yorumlamaları istenmiştir. $\mathrm{Bu}$ soruya ait TA kategorisinde, "NO gazının bileşenlerine ayrıldığı için derişimi düşmüştür, tepkimede tamamen tükenmiştir." ifadesi yer almaktadır. Ön-testte, deney grubu öğrencilerinin $\% 35$ 'i, kontrol grubu öğrencilerinin \%59'u bu kategoriye giren cevabı verirken, sontestte bu oran deney grubu öğrencilerinde \%81, kontrol grubu öğrencilerinde ise \%77 olmuştur. Öğrencilerin "NO gazının derişimi azalmıştır.", "NO gazı tükenmiştir." ifadeleri KA kategorisinde değerlendirilirken deney grubu öğrencilerinin \%15'i, kontrol grubu öğrencilerinin de \%18'i ön-testte bu kategoriye giren cevapları vermişlerdir. Son-testte ise her iki grupta da bu kategoriye giren cevaba rastlanmamıştır. Deney grubu öğrencilerinin \%8'i ön-testte, "NO gazı çözündüğü için derişim düşmüştür.” biçiminde bir açıklamada bulunmuş ve SKYKA kategorisinde yer almışlardır. Son-testte ise hem deney hem de kontrol grubu öğrencilerinde bu kategoriye rastlanmıştır. Bu soruyla ilgili SKY kategorisine sadece kontrol grubu öğrencilerinde ön-testte \%5 oranında rastlanmıştır. $\mathrm{Bu}$ kategorideki öğrenci, grafiği yanlış yorumlamış ve NO gazının derişiminin arttığını ifade etmiştir.

3. sorunun $\mathrm{b}$ alt maddesinde, NO gazının başlangıç derişiminin arttırılmasının reaksiyon hızını nasıl etkilediği sorulmuştur. "NO gazının derişimi arttırıldığında, birim zamandaki çarpışma sayısı artacağı için reaksiyon hızı da artar.” ifadesi TA kategorisi olarak alınmıştır. Ön-testte, her iki grupta da bu soruya TA kategorisine giren cevabı veren olmamıştır. Son-testlerde ise, bu kategorinin oranı artmış, deney grubunda \% 77 , kontrol grubunda ise \%41 olmuştur. KA kategorisinde ise, öğrenciler "Reaksiyon hızı artar." ifadesini kullanmışlar ancak bunun nedenini açıklayamamışlardır. Ön-testte deney grubu öğrencilerinin \%23'ü, kontrol grubu öğrencilerin ise \%27'si bu kategoriye giren cevabı verirken, son-testte bu oran deney grubunda \%19'a düşerken, kontrol grubunda \%45'e yükselmiştir. SKYKA kategorisinde ise "Reaksiyon hızı önce artar sonra sabit kalır." ifadesi yer almaktadır. Ön-testte deney grubu öğrencilerinin \%4'ü, kontrol grubu öğrencilerinin \%5'i bu kategorideyken, son- testte bu kategori her iki grupta da saptanmamıştır. Öğrencilerde, öğretim öncesi ve sonrası önemli bir değişimin gözlendiği kategori ise SKY kategorisinde olmuştur. $\mathrm{Bu}$ kategoride "NO gazı derişiminin artırılması, reaksiyon hızını düşürür.", "NO gazı derişiminin artırılması, reaksiyon hızını etkilemez." ifadeleri yer almakta olup bu kategori ön-testte deney 
grubu öğrencilerinde $\% 58$, kontrol grubu öğrencilerinde ise $\% 45$ oranında olmuştur. Son-testte ise deney grubu öğrencilerinde bu kategoriye rastlanmazken, kontrol grubu öğrencilerinde oran $\% 5$ 'e düşmüştür.

Sıcaklık artışının reaksiyon hızını nasıl etkilediğinin sorulduğu 3. sorunun c alt maddesinde, TA kategorisinde "Sıcaklığın arttırılması endotermik ve ekzotermik tepkimelerde, birim zamanda çarpışan tanecik sayısını arttıracağından reaksiyon hızını arttırır." ifadesi yer almaktadır. Deney ve kontrol grubu öğrencilerinden ön-testte bu kategoriye giren cevap veren olmazken, son-testte ise deney grubu öğrencilerinin \%27'si, kontrol grubu öğrencilerinin \%14' ü bu kategoridedir. KA kategorisi, ön-testte, en yüksek anlama düzeyine sahip olan kategori olmuştur. Bu durum şaşırıcı olmamıştır, çünkü öğrenciler ön bilgilerine dayanarak da "Sıcaklık artışının reaksiyon hızını arttırdığını." belirtmiş ancak bunun nedenini açıklayamamışlardır. Ön-testte deney grubunda \%58 olan bu oran son-testte \%66'ya, kontrol grubunda ise \%41'den \%68'e çıkmıştır. Bu sorudaki kategorilerden biri de SKYKA kategorisidir. Bu kategori de "Sıcaklığın arttırılması reaksiyonu hızlandırır ancak daha çok 1sıtırsak reaksiyon yavaşlar.", "Reaksiyon hızı belli bir noktaya kadar artar sonra durur." ifadeleri yer almaktadır. Ön-testte deney grubu öğrencilerinin \%4’ü, kontrol grubu öğrencilerinin $\% 9$ 'u bu kategoride iken, son-testte her iki grupta da bu kategoriye giren cevaba rastlanmamıştır. Ön-testte ortaya çıkan kategorilerden biri olan SKY kategorisinde ise öğrencilerin "Sıcaklığın arttırılması, reaksiyon ekzotermik olduğundan hızı azaltır.," ifadesi yer almaktadır. Deney ve kontrol grubu öğrencilerinde ön-testte $\% 27$ oranında olan bu kategori, son-testte azalmış deney grubunda $\% 8$, kontrol grubunda $\% 9$ olmuştur.

3. sorunun bir diğer alt maddesi olan $d$ alt maddesinde, katı katalizör miktarının arttırılmasının reaksiyon hızını nasıl etkilediği sorulmuştur. Bu soruda öğrencilerden, "Katalizör tepkimeden bir değişikliğe uğramadan çıkar, bu nedenle miktarının arttırılması reaksiyon hızını değiştirmez." ifadesini diyerek TA kategorisinde giren cevabı vermeleri beklenmiştir. Ön-testte her iki grupta da TA kategorisine giren cevabı veren olmamakla birlikte, son-testte ise deney grubu öğrencilerinin \%23'ü, kontrol grubu öğrencilerinin \%9'u TA kategorisine giren cevap verebilmişlerdir. KA kategorisinde ise öğrenciler "Katalizör miktarının arttırılması hızı değiştirmez." şeklinde bir ifade kullanmışlar ancak bu duruma açıklık getirememişlerdir. Ön-testte deney grubu öğrencilerinin bu kategorideki oranı \%4 iken, son-testte $\% 58$ 'e, kontrol grubunda ise \%9'dan \%27'ye çıkmıştır. "Katalizör miktarı arttırılırsa reaksiyon hızı da artar", "Katalizör miktarı arttırılırsa reaksiyon hızı azalır." ifadeleri ise ön-testte SKY kategorisinde yer alan ifadelerdendir. Ön-testte deney grubu öğrencilerinin \%85'i, kontrol grubu öğrencilerinin ise \%68'i SKY kategorisine giren cevapları verirken, sontestlerde her iki grupta da bu oran düşmüştür. Ancak deney grubu öğrencileri \%8 gibi düşük bir oranda bu kavram yanılgılarına sahip iken, kontrol grubunda ise bu oran $\% 50$ olmuştur.

4. sorunun a alt maddesinde, reaksiyondaki reaktiflerden birine ait derişimzaman grafiği verilmiş, öğrencilerden bu grafiği dikkate alarak çizilen hız-zaman grafiklerinden hangisinin doğru olabileceği sorulmuş ve kendilerinin de bu grafiği 
çizmeleri istenmiştir. Sorunun TA kategorisinde, öğrencilerden çizilen grafiklerden ikisinin de doğru olmadığını belirtmeleri ve tepkime hızının zamanla azalacağı bir grafiği çizmeleri beklenmiştir. Ön-testte, deney grubu öğrencilerinin \%4'ü, kontrol grubu öğrencilerinin \%9'u bu kategoride yer alırken, son-testte deney grubunda bu oran \%85'e, kontrol grubunda ise \%59'a çıkmıştır. SKY kategorisinde ise öğrenciler tepkime hızı-zaman grafiğini yanlış çizmişlerdir. Deney grubu için ön-testte bu kategorinin oranı $\% 85$, kontrol grubu için \%77 iken, son-testte bu oran deney grubunda \%12'ye kontrol grubunda ise \%32'ye düşmüştür. Deney ve kontrol grubu öğrencilerinin ön ve son-testte çizmiş oldukları grafik örneklerinden bazıları Şekil 2'de sunulmuştur.

Şekil 2. Deney ve Kontrol Grubu Öğrencilerinin Ön ve Son-Testte 4-a Sorusu için Çizdikleri Grafik Örnekleri

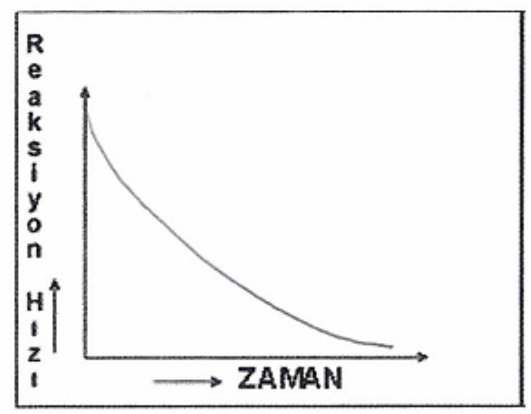

K.Ö-1 (Ön-test)

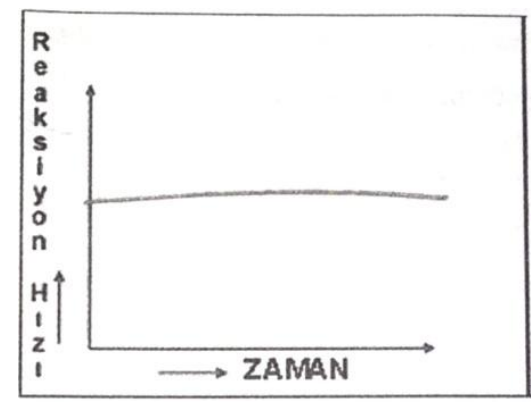

K.Ö-2 (Ön-test)

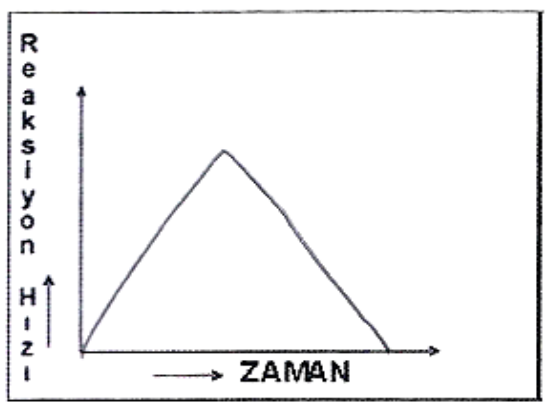

D.Ö-5(Ön-test)

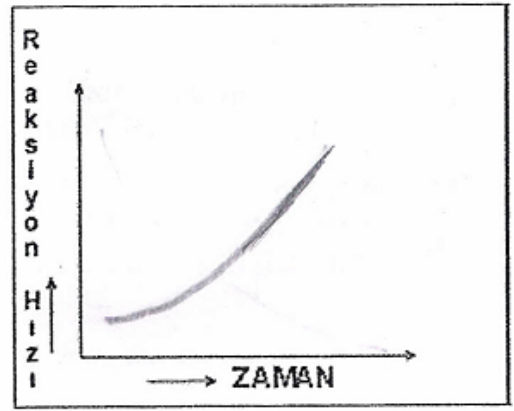

K.Ö-1 (Son-test)

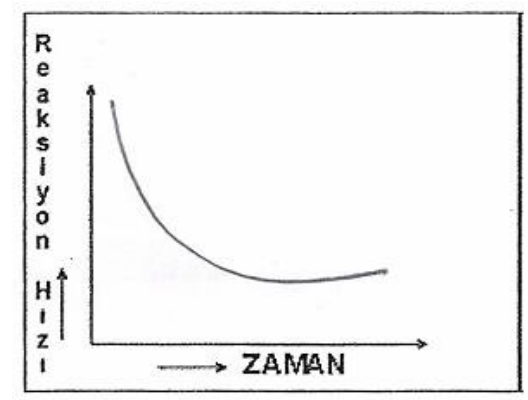

K.Ö-2 (Son-test)

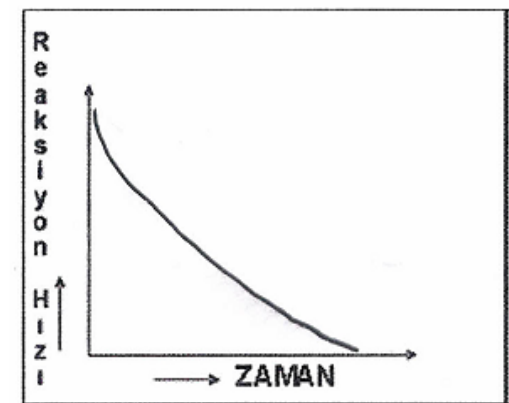

D.Ö-5(Son-test) 


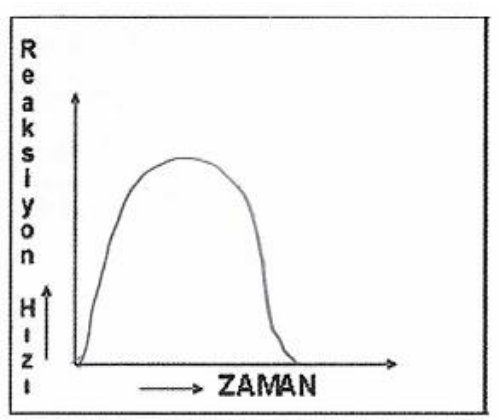

D.Ö-15(Ön-test)

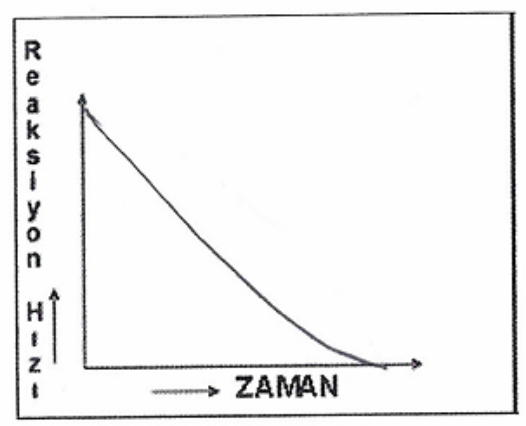

D.Ö-15(Son-test)

4. sorunun $b$ alt maddesinde, öğrencilerden bir üst basamakta çizdikleri grafiği açıklamaları istenmiş ve "Tepkimedeki reaktiflerin derişimi azaldıkça, tepkime hızı da azalmıştır." şeklindeki ifade TA kategorisinde değerlendirilmiştir. Deney grubunda öntestte bu kategoriye giren cevap saptanamazken, kontrol grubunda bu oran $\% 5$ olmuştur. Son-testte ise TA kategorisi deney grubunda \%38, kontrol grubunda \%9 olarak belirlenmiştir. Öğrenciler aynı zamanda "Tepkime hızının zamanla azalacağını." ifade etmişler ancak bu durumun nedenini açıklamadıkları için KA kategorisine giren cevapları vermişlerdir. Bu kategorinin, ön-testte deney grubundaki oranı $\% 4$ iken, sontestte bu oran \%31'e yükselmiştir. Kontrol grubu için ise, ön-testte saptanamayan bu kategorinin oranı son-testte $\% 45$ 'e ulaşmıştır. Ön-testte ortaya çıkan kategorilerden biri SKYKA kategorisidir. Bu kategoride "Reaksiyona giren madde miktarı başlangıçta fazla olduğundan tepkime hızı bir süre artar, girenler azaldıkça reaksiyon hızı azalır." ifadesi yer almaktadır. Ön-testte deney grubu öğrencilerinin \%12'si, kontrol grubu öğrencilerinin \%18'i bu kategoriye giren cevabı verirken, son-testte deney ve kontrol gruplarında bu kategori saptanamamıştır. "Reaktif derişimin azalması reaksiyon hızını artırır.", "Homojen ortamlarda reaksiyon hızı değişmez." ve "Giren ve ürünler aynı olduğu için reaksiyon hızı da aynıdır." ifadeleri SKY kategorisinde giren ifadeler olmuştur. Deney grubu öğrencilerinin \%50'si ön-testte bu kavram yanılgılarına sahip iken, son-testte bu yanılgılara rastlanmamıştır. Kontrol grubunda son-testte bu kavram yanılgılarında azalma görülse de, öğrencilerin \%18'i bu kavram yanılgılarına hala sahiptir.

Bir tepkimeye ait derişim-zaman grafiğinin verildiği 5 . sorunun a alt maddesinde, öğrencilerden reaksiyonun kaç adımdan oluştuğunu ve mekanizmalı ise bu adımlarının neler olduğunu açıklamaları istenmiştir. TA kategorisinde, öğrencilerin "Reaksiyonun iki adımdan oluştuğunu ve bu adımlarını X $\rightarrow \mathrm{J}$ (Hızlı), J $\rightarrow$ Q (Yavaş)." olarak belirtmeleri istenmiştir. Deney grubu öğrencilerinin \%8'i, kontrol grubu öğrencilerinin \%14'ü ön-testte bu kategoriye giren cevabı verirken, son-testte bu oran deney grubunda \%58'e, kontrol grubunda ise \%32'ye yükselmiştir. KA kategorisinde ise öğrencilerin tepkimenin 2 adımdan oluştuğunu belirttikleri ancak bu adımların neler olduğunu açıklayamadıkları belirlenmiştir. Ön-testte her iki grupta da bu kategorinin oran1 \%23 olurken, son-testte bu oran deney grubunda \%19'a düşerken, kontrol grubunda \%45 olmuştur. Ön-testte, sadece deney grubu öğrencilerinde \%12 oranında 
belirlenen kategori SKYKA kategorisi olmuştur. $\mathrm{Bu}$ kategorideki öğrenciler "Reaksiyonun iki adımdan oluştuğunu." belirtmiş ancak yavaş ve hızlı adımları yanlış belirtmişlerdir. Son-testte ise, ön-testteki gibi sadece deney grubu öğrencilerinin $\% 12$ 'sinde bu kategori ortaya çıkmıştır. " $\mathrm{X} \rightarrow \mathrm{Q}$ reaksiyonu tek adımlıdır, çünkü bir giren ve bir ürün bulunur.”, " $\mathrm{X} \rightarrow \mathrm{Q}$ reaksiyonu 3 adımlıdır, çünkü derişim-zaman grafiğinde üç eğri vardır." ve " $\mathrm{X} \rightarrow \mathrm{Q}$ reaksiyonu 4 adımlıdır çünkü reaksiyon hazırlık, giriş, reaksiyonun hızlanması ve ürünlerin oluşması şeklindeki basamaklardan oluşur." ifadeleri SKY kategorisinde değerlendirilmiştir. Deney grubunda ön-testteki oranı \%38 olan bu kategori, son-testte saptanmamıştır. Kontrol grubunda ise ön-testteki \%45 olan bu oran, son-testte $\% 5$ 'e düşmüştür.

5. sorunun $\mathrm{b}$ alt maddesinde ise, öğrencilerden reaksiyon birden fazla adımdan oluşuyorsa hızlı basamağı ve reaksiyonun hızını belirleyen basamağın hangileri olduğunu, bunları nasıl belirlediklerini açıklamaları istenmiştir. Öğrencilerin derişimzaman grafiğini dikkate alarak, girenlerin tükenme süresi daha kısa olduğundan 1. adımın hızlı, 2. adımın yavaş ve 2. adımın hızı belirleyen basamak olduğunu belirten ifadeleri TA kategorisinde yer almıştır. Her iki grupta da ön-testte bu kategorinin oranı düşük olup, deney grubu için \%4, kontrol grubu için \%5 olarak saptanmıştır. Sontestlerde ise bu oran artmış, deney grubunda \%31, kontrol grubunda ise $\% 9$ olmuştur. Bazı öğrenciler ise "1. adımın hızlı, 2. adımın ise yavaş olduğunu ve hızı, yavaş olan ikinci basamağın belirleyeceğini.” ifade etmişler ancak bunu açıklayamadıkları için cevapları KA kategorisinde değerlendirilmiştir. Deney grubunda, ön-testte $\% 8$ olan bu oran son-testte \%23'e çıkmış, kontrol grubunda ise son-testte \%45 olmuştur. Öğrencilerin "1. adım daha hızlıdır ve reaksiyon hızını belirler.", “1. adım hızlıdır çünkü girenlerin miktarı fazladır." ve "Hızı 2. adım belirler çünkü daha hızlıdır." ifadeleri incelendiğinde, basamakları doğru saptasalar bile hızı belirleyen basamakla ilgili yanılgılarının olduğu anlaşılmaktadır. $\mathrm{Bu}$ nedenle bu ifadeler SKYKA kategorisinde değerlendirilmiştir. Ön-testte deney grubunda \%12, kontrol grubunda ise $\% 5$ olan bu kategori son-testte her iki grupta da saptanmamıştır. "Reaksiyonun 1.adımı yavaş, 2. adımı hızlıdır çünkü 1. adımda zor tepkimeler olur.", "reaksiyonun 1. adımı hızlı, 2. adım daha yavaş, 3. adımı ise en yavaştır çünkü her basamakta tepkime hızı daha da düşer." ve "Katalizörün kullanıldığ 1 2. adım hızlıdır" ifadeleri SKY kategorisindeki ifadelerdendir. Bu kategorinin oranı ön-testte deney grubunda \%38, kontrol grubunda $\% 27$ iken, son-testte sırasıyla $\% 19$ ve $\% 18$ olmuştur.

6. soru ise aynı sıcaklıkta gerçekleşen biri endotermik diğeri egzotermik olan iki reaksiyonun hızlarının karşılaştırılmasını içermektedir. TA kategorisinde öğrencilerin, "Reaksiyonların aktifleşme enerjileri verilmediği için bu bilgilere dayanarak bir yorum yapılamayacağı." cevabını vermeleri hedeflenmiştir. Ön-testte deney grubu öğrencilerinin \%12'si, kontrol grubu öğrencilerinin \%18'i bu kategoriye giren cevab1 verirken, son-testte bu oran deney grubunda \%35'e ç1karken, kontrol grubunda \%5'e düşmüştür. Bir kısım öğrenci ise, iki reaksiyonun hızı hakkında yorum yapılamayacağını belirtmiş ancak bunun nedenini açıklayamamış ve bu nedenle KA kategorisinde yer almıştır. Ön-testte her iki grupta da bu kategori ortaya çıkmazken, 
son-testte bu oran deney grubunda $\% 4$, kontrol grubunda ise $\% 18$ olmuştur. Kavram testinde, en çok spesifik kavram yanılgılarının ortaya çıktığı sorulardan biri 6. soru olmuştur. "Endotermik reaksiyon daha hızlıdır.", "Ekzotermik reaksiyon daha hızlıdır.", "İki reaksiyonun hızları aynıdır, çünkü sıcaklıkları aynıdır.", "Başlangıçta iki reaksiyonun hızları aynıdır, fakat ekzotermik reaksiyon ısı verdiği için yavaşlar, endotermik reaksiyon ise 1Sı aldığı için hızlanır." ifadeleri SKY kategorisinde yer alan ifadelerdir. Deney grubu öğrencilerinin \%81'i ön-testte, bu kategorideki kavram yanılgılarına sahip iken, son-testte bu oran \%54'e düşmüştür. Kontrol grubunda ise ön ve son-testlerde bu kategorinin oranında bir değişim gözlenmemiş ve \%59 gibi yüksek bir oranda kalmıştır.

Heterojen bir tepkimenin verildiği 7. sorunun a alt maddesinde, öğrencilere kaplardan hangisinde gerçekleşen reaksiyonun daha hızlı olduğu sorusu yöneltilmiştir. Öğrencilerin "Toz $\mathrm{MgO}$ reaksiyonu, temas yüzeyi farkından dolayı daha hızlı gerçekleşir." cevabı TA kategorisinde değerlendirilmiştir. Ön-testte deney grubunda $\% 73$ olan bu kategorinin oran1, son-testte \%81'e kontrol grubunda ise \%59'dan \%73'e çıkmıştır. KA kategorisinde ise öğrenciler "İki reaksiyonun hızının farklı olduğunu." belirtmiş ancak hangisinin daha hızlı olduğuna açıklık getirememişlerdir. Ön-testte sadece deney grubu öğrencilerinin \%4'ünde karşılaşılan bu kategori, son-testte her iki grupta da ortaya çıkmamıştır. "İki reaksiyonun hızları aynıdır." ifadesi SKY kategorisinde yer almış olup, ön-testte deney grubu öğrencilerinin \%12'sinde, kontrol grubunda ise \%18'inde saptanmıştır. Son-testlerde her iki grupta da bu oran değişmemiştir.

7. sorunun $\mathrm{b}$ alt maddesinde ise öğrencilerden bir üst maddede verdikleri cevapları açıklamaları istenmiş ve "Toz MgO kullanıldığı reaksiyonda, reaksiyonun gerçekleştiği yüzey alanı daha fazla olduğu için, reaksiyon daha hızlı olur." ifadesi TA kategorisi olarak alınmıştır. Ön-testte deney grubunda bu kategorinin oranı $\% 65$, kontrol grubunda $\% 50$ olurken, son-testte deney grubunda $\% 81$ 'e kontrol grubunda ise $\% 68$ 'e çıkmıştır. Bazı öğrenciler ise "Toz $\mathrm{MgO}$ daha hızlı tepkimeye girer." ifadesini kullanarak KA kategorisine giren cevabı vermiştir. Bu kategoriye ön-testte $\% 4$ oranında sadece deney grubunda rastlanırken, son testte tersi bir durum ortaya çıkmış ve bu oran kontrol grubunda \%14 olarak saptanmıştır. SKYKA kategorisinde ise "Toz MgO reaksiyonu hızlıdır çünkü toz halindeyken kendi aralarında bir bağ yoktur." ifadesi yer almış olup, bu kategoriye sadece ön-testte deney grubunda \%4 oranında rastlanmıştır. Öğrencilerin bu soruya verdikleri cevaplardan "Kullanılan $\mathrm{HCl}$ ve $\mathrm{MgO}$ miktarları aynı olduğu için iki tepkimenin hızları da aynıdır." ifadesi SKY kategorisinde yer almıştır. Ön-testte deney grubunda \%15, kontrol grubunda \% 14 olan bu kategorinin oranı sontestte deney grubunda $\% 4$ 'e kontrol grubunda ise $\% 5$ 'e düşmüştür.

Bir diğer soru olan 8. sorunun a maddesinde, öğrencilerden aktivasyon enerjisini açıklamaları istenmiştir. "Tepkimenin başlaması için gerekli olan minimum enerjidir." ifadesi TA kategorisi olarak alınmıştır. Ön-testte deney grubunda \%50 olan bu kategorinin oran1, son-testte \%81'e, kontrol grubunda ise \%41'den \%73'e çıkmıştır. "Aktivasyon enerjisi reaksiyona girenlerin kinetik enerjisidir.", "Aktivasyon enerjisi 
reaksiyona girenlerin potansiyel enerjisidir.", "Aktivasyon enerjisi tepkimenin gerçekleşmesi için gerekli sıcaklıktır." ve "Aktivasyon enerjisi tepkimedeki toplam enerji miktarıdır." ifadeleri SKY kategorisindeki kavram yanılgılarıdır. Bu kategori, öntestte deney grubunda $\% 42$, kontrol grubunda \%32 oranında olurken, son-testte ise her iki grupta azalmış ve deney grubunda \%12'ye, kontrol grubunda \%18'e düşmüştür.

8. sorunun $\mathrm{b}$ maddesinde, öğrencilerden aktifleşme enerjileri verilen iki reaksiyonun hızlarını karşılaştırmaları istenmiştir. Sorunun TA kategorisinde "1. reaksiyon daha hızlıdır çünkü aktivasyon enerjisi diğer reaksiyona göre daha düşüktür, aktivasyon enerjisi düşükse bu enerjiye ulaşmak daha kolay olacağı için reaksiyon daha hızlı olur." ifadesi yer almaktadır. Ön-testte bu kategorinin oranı deney grubunda \%31, kontrol grubunda \%27 olurken, son-testte bu oran deney grubunda \%69'a çıkarken, kontrol grubunda \%18'e düşmüştür. KA kategorisine giren ifadede ise öğrenciler " 1 . reaksiyonun daha hızlı" olduğunu belirtmişler ama bunun nedenini açıklayamamışlardır. Ön-testte deney grubunda $\% 8$, kontrol grubunda $\% 5$ olan bu kategorinin oran1, sontestte her iki grupta da artmış, deney grubunda $\% 23$, kontrol grubunda $\% 14$ olmuştur. "1. reaksiyon hızlıdır çünkü daha az 1sı almıştır." ifadesi SKYKA kategorisinde değerlendirilmiştir. Bu kategori, ön-testte sadece deney grubunda \%4 oranında saptanırken, son-testte de aynı durum ortaya çıkmıştır. "Aktivasyon enerjisi fazla olan reaksiyon hızlıdır." ve "Aktivasyon enerjilerine göre reaksiyonların hızlarını karşılaştırmak mümkün değildir." ifadeleri ise SKY kategorisinde yer alan kavram yanılgılarıdır. Ön-testte bu kategorinin deney grubundaki oranı \%54, kontrol grubunda $\% 45$ iken, son-testte deney grubunda bu kategoriye giren herhangi bir cevap yer almaktadır. Kontrol grubunda ise bu oran artmış ve \%50 olmuştur.

Kavram testinin en son sorusu olan 9. soruda katalizörün reaksiyonlar üzerindeki çeşitli etkileri ele alınmıştır. Bunlardan katalizörün reaksiyon hızını nasıl etkilediği 9. sorunun $\mathrm{a}_{1}$ maddesinde ele alınmıştır. $\mathrm{Bu}$ sorunun TA kategorisinde "Katalizör, aktivasyon enerjisini azaltarak reaksiyonu hızlandırır." ifadesi yer almaktadır. Ön-testte deney grubunda $\% 8$ olan bu kategorinin oranı, son-testte $\% 73$ 'e çıkmıştır. Kontrol grubunda ise ön-testteki \%5'lik oran, son-testte yükselmiş ancak \%18 olmuştur. Öntestte en yüksek orana sahip kategorilerden biri KA kategorisi olmuştur. Bu durumun en önemli nedenlerinden biri, öğrencilerin katalizör ya da enzimlerin tepkime hızı üzerindeki etkisi ön bilgisine sahip olmalarıdır. Bu kategoride öğrenciler "Katalizör reaksiyon hızını artırır." ifadesini kullanmışlarsa da bunu aktivasyon enerjisi ile ilişkilendirememişlerdir. Deney grubu öğrencilerinin \%69'u, kontrol grubu öğrencilerinin ise \%68'i ön-testte bu kategoriye giren cevabı vermişlerdir. Son-testte ise bu oran deney grubunda \%23'e düşerken, kontrol grubunda artmış ve \%77 olmuştur. Ön-testte ortaya çıkan kategorilerden bir olan SKYKA kategorisinde ise "Katalizör, reaksiyon hızını artırır çünkü reaksiyonun başında bulunarak reaksiyona girer." ve "Katalizör, reaksiyon hızını artırır çünkü reaksiyonun oluşması için uygun ortam sağlar." ifadeleri yer almıştır. Bu kategori ön-testte sadece kontrol grubunda \%9 oranında ortaya çıkmıştır. SKY kategorisinde ise yer alan "Katalizörün, reaksiyon hızına etkisi yoktur." ve "Katalizör, reaksiyon hızını azaltır." ifadeleri ön-testte deney 
grubu öğrencilerinin \%15'inde, kontrol grubu öğrencilerinin ise $\% 5$ 'inde ortaya çıkmıştır. Son-testte her iki grupta da bu kavram yanılgılarına rastlanmamıştır.

9. sorunun $\mathrm{a}_{2}$ maddesinde, katalizörün aktivasyon enerjisini nasıl etkilediği sorulmuş ve "Katalizör, tepkime mekanizmasına etki ederek aktivasyon enerjisini düşürür." cevabı TA kategorisinde alınmıştır. Ön-testte deney grubunda $\% 8$ olan bu kategorinin oranı, son-testte \%73'e, kontrol grubunda ise \%14'den \%18'e çıkmıştır. "Katalizör, aktivasyon enerjisini azaltır." ifadesi ise KA kategorisinde yer almakta olup, ön-testte deney grubu öğrencilerinin \%42'si, kontrol grubunun ise \%18'i bu kategoriye giren cevabı vermiştir. Son-testte ise bu oran, deney grubunda \%19'a düşerken, kontrol grubunda \%59'a çıkmıştır. SKYKA kategorisinde değerlendirilen; “Tepkime kısa süreceği için aktivasyon enerjisi düşer." ifadesine ise sadece ön-testte deney grubunda \%8 oranında rastlanmıştır. "Katalizör ilavesi aktivasyon enerjisini artırır." ve "Katalizör ilavesi aktivasyon enerjisini etkilemez." ifadeleri SKY kategorisinde değerlendirilmiş olup, ön-testte deney grubunda $\% 31$, kontrol grubunda $\% 50$ olan bu kategori, son-testte deney grubunda ortaya çıkmazken, kontrol grubunda \%18 olarak belirlenmiştir.

Katalizörün ürün oluşumunu nasıl etkilediği 9. sorunun $\mathrm{a}_{3}$ maddesinde sorulmuş olup, "Giren madde miktarı aynı olduğu için katalizör, oluşan ürün miktarını etkilemez, sadece reaksiyonu hızlandırır." ifadesi TA kategorisinde değerlendirilmiştir. Ön-testte, bu kategorinin oranı deney grubunda \%4, kontrol grubunda \%14 iken, son-testte deney grubunda bu oran \%19'a yükselirken, kontrol grubunda ise bir değişim saptanmamıştır. $\mathrm{Bu}$ sorudaki en yüksek orana sahip kategori, KA kategorisi olmuştur. Bu kategoride öğrenciler, "Katalizörün ürün oluşumunu etkilemediğini, sadece hıza etki ettiğini belirtmişler." ancak bu durumu açıklayamamışlardır. Ön-testte deney grubunda \%42 olan bu kategorinin oranı, son-testte \%77'ye çıkmış ancak kontrol grubunda ön-testteki \%59'luk oran değişmemiştir. "Katalizör, ürün oluşmasını etkiler çünkü aynı sıcaklıkta aktivasyon enerjisi azalacağından tepkime hızlanır ve daha çok ürün oluşur." ifadesi ise SKYKA kategorisinde değerlendirilmiştir. Bu kategoriye sadece ön-testte deney grubu öğrencilerinin \%4'ünde rastlanmıştır. "Katalizör, oluşan ürün miktarını artırır.", "Katalizör, oluşan ürün miktarını azaltır."ve "Katalizör kullanıldığında farklı ürün oluşur." ifadeleri ise SKY kategorisinde değerlendirilmiştir. Bu kategorinin ön-testte deney grubundaki $\% 42$ olan oran1, son-testte \%4'e düşerken, kontrol grubunda ise $\% 14$ 'den \%23'e çıkmıştır.

9. sorunun $\mathrm{a}_{4}$ maddesinde, katalizörün reaksiyon mekanizması üzerindeki etkileri sorulmuştur. Sorunun TA kategorisinde "Katalizör, tepkimeyi aktifleşme enerjisi düşük olan farklı reaksiyonlar üzerinden yürüterek, reaksiyon mekanizmasını etkiler." ifadesi yer almakta olup, ön-testte deney grubu öğrencilerinde bu kategoriye rastlanmazken, son-testte \%31 gibi bir oran ortaya çıkmıştır. Kontrol grubunda ise deney grubunun aksine, ön-testte \%9'luk orana sahip olan bu kategoriye, son-testte rastlanmamıştır. Öğrencilerin verdikleri cevaplardan "Katalizör, reaksiyon mekanizmasını değiştirir.", "Katalizör, reaksiyon mekanizmasını etkiler." ve "Katalizör, reaksiyonun adım sayısını artırır" ifadeleri KA kategorisinde değerlendirilmiştir. Öntestte bu kategorinin oranı deney grubunda \%27, kontrol grubunda \%14 iken, son-testte 
her iki grupta da artmış ve deney grubunda \%62, kontrol grubunda ise \%68 olmuştur. SKYKA kategorisinde ise "Katalizör, reaksiyonun mekanizmasını etkileyerek iki adımlı tepkimeyi tek adıma düşürür" ifadesi yer almış ve bu kategori sadece deney grubunda ön-testte \%4 oranında ortaya çıkmıştır. "Katalizör ilavesi, reaksiyon mekanizmasını etkilemez." ve "Katalizör ilavesi, reaksiyon mekanizmasını azaltır." ifadeleri ise öğrencilerin sahip oldukları kavram yanılgılarından olup SKY kategorisinde değerlendirilmiştir. Deney grubunda ön-testte \%54 oranında olan bu kategori, son-testte \%8'e, kontrol grubunda ise \%59'dan \%23'e düşmüştür.

9. sorunun $b$ maddesinde öğrencilere, katalizör kullanılmayan bir reaksiyona ait reaksiyon koordinatı-enerji grafiği verilmiş ve öğrencilerden katalizörlü bir tepkimeye ait grafiği çizmeleri istenmiştir. Ön-testte sadece deney grubu öğrencilerinin \%4'ü bu grafiği doğru çizmiş ve TA kategorisinde yer almıştır. Son-testte geçildiğinde ise her iki grupta da istenilen grafiği doğru bir biçimde çizen öğrenci sayısı artmış ve deney grubunda \%62, kontrol grubunda ise \%23'e ulaşmıştır. SKY kategorisinde değerlendirilen grafiklerde ise, öğrencilerin çoğunlukla reaktif ve ürünlerin potansiyel enerjileri ile tepkime entalpisini değiştirerek grafik çizdikleri saptanmıştır. Deney grubunda ön-testte $\% 73$ olan bu oran \%27'ye; kontrol grubunda \%77'den \%55'e düşmüştür. Deney ve kontrol grubu öğrencilerinin ön ve son-testte çizmiş oldukları grafik örneklerinden bazıları Şekil 3'de gösterilmiştir.

Şekil 3. Deney ve Kontrol Grubu Öğrencilerinin Ön ve Son-Testte 9-b Sorusu için Çizdikleri Grafik Örnekleri

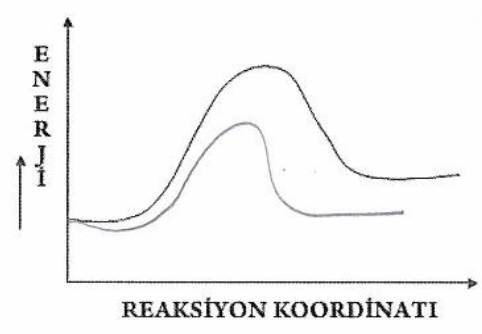

K.Ö-13(ön-test)

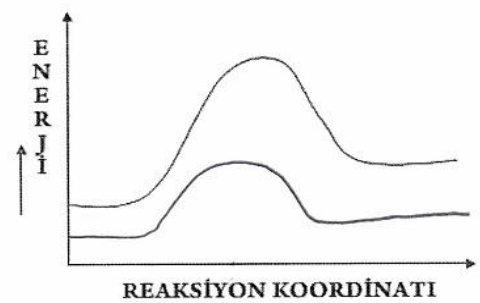

K.Ö-21(ön-test)

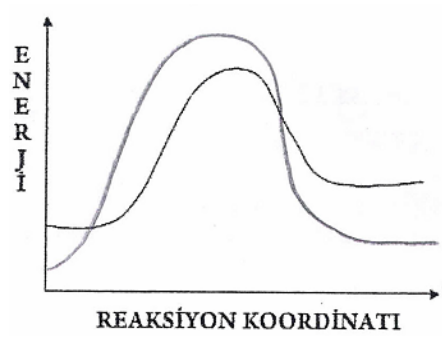

K.Ö-13(son-test)

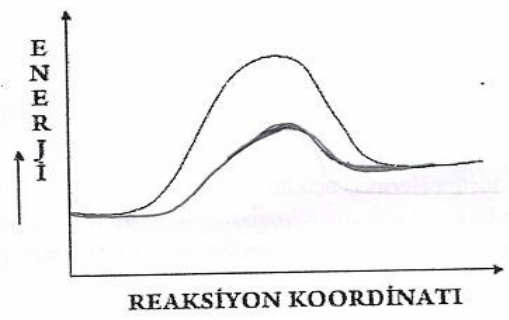

K.Ö-21(son-test) 


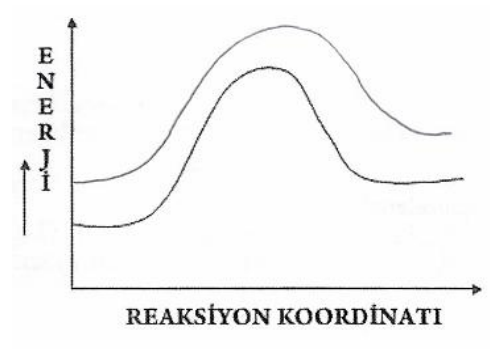

D.Ö-17 (ön-test)

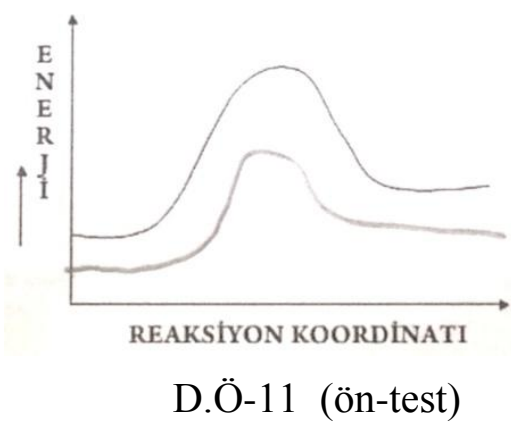

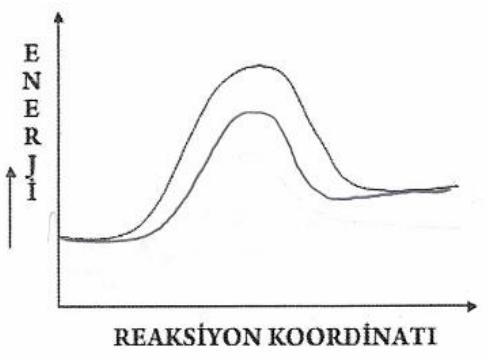

D.Ö-17(son-test)

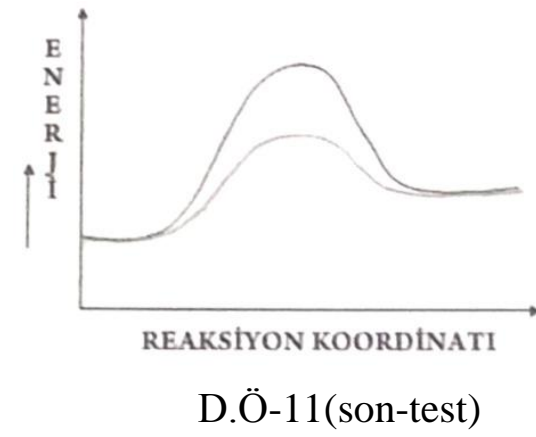

Kavram testinin en son sorusu olan 9. sorunun c maddesinde, öğrencilerden çizdikleri grafiği açıklamaları istenmiştir. Sorunun TA kategorisinde "Katalizör, reaksiyona giren ve ürünlerin enerjisini değiştirmeyip, sadece aktivasyon enerjisini düşürmüştür." ifadesi yer almaktadır. Ön-testte deney ve kontrol gruplarında, bu kategoriye giren cevaba rastlanmazken, son-testlerde de bu kategori sadece deney grubunda $\% 8$ oranında ortaya çıkmıştır. "Katalizör, aktivasyon enerjisini düşürür." ve "Katalizör sayesinde reaksiyonun başlaması için gereken enerji düşer." ifadeleri KA kategorisinde değerlendirilmiştir. Bu kategorinin ön-testte deney grubundaki oran $1 \% 4$, kontrol grubundaki oran 1 ise $\% 9$ iken; son-testte deney grubunda \%46\%ya, kontrol grubunda ise \%41'e çıkmıştır. "Katalizör, aktivasyon enerjisi ile birlikte giren ve ürünlerin de enerjisini düşürür." ifadesi SKYKA kategorisinde değerlendirilmiş olup bu kategori sadece ön-testte deney grubunda \%4 oranında ortaya çıkmıştır. "Katalizör ilavesi, aktivasyon enerjisini artırır." kavram yanılgısı da SKY kategorisinde yer almış olup, bu yanılgıya sadece ön-testte kontrol grubunda \%9 oranında rastlanmıştır.

Araştırmanın dördüncü alt problemi olan "Deney ve kontrol gruplarında uygulanan öğretim yöntemlerinin kavramsal değişimin sağlanmasında bir etkisi var mıdır?" sorusunu cevaplamak amaciyla, ön ve son-testlerde saptanan spesifik kavram yanılgılarının yüzdeleri arasındaki fark, kavramsal değişimin yüzdesi olarak hesaplanmış ve bunlar Tablo 7'de gösterilmiştir.

Tablo 7 incelendiğinde, ön-testte deney ve kontrol gruplarında saptanan kavram yanılgılarının benzer yüzdelerde olduğu görülmektedir. Buna karşın, son-testte ise deney grubunda daha az kavram yanılgısının olduğu anlaşılmaktadır. Örneğin, sontestte deney grubunda kavram yanılgılarının oranı \%4 ile \%31 arasında değişirken, kontrol grubunda bu oran $\% 5$ ile $\% 46$ arasında değişmektedir. 
Tablo 7

Ön ve Son-Testte Saptanan Kavram yanılgıları ve Yüzdeleri

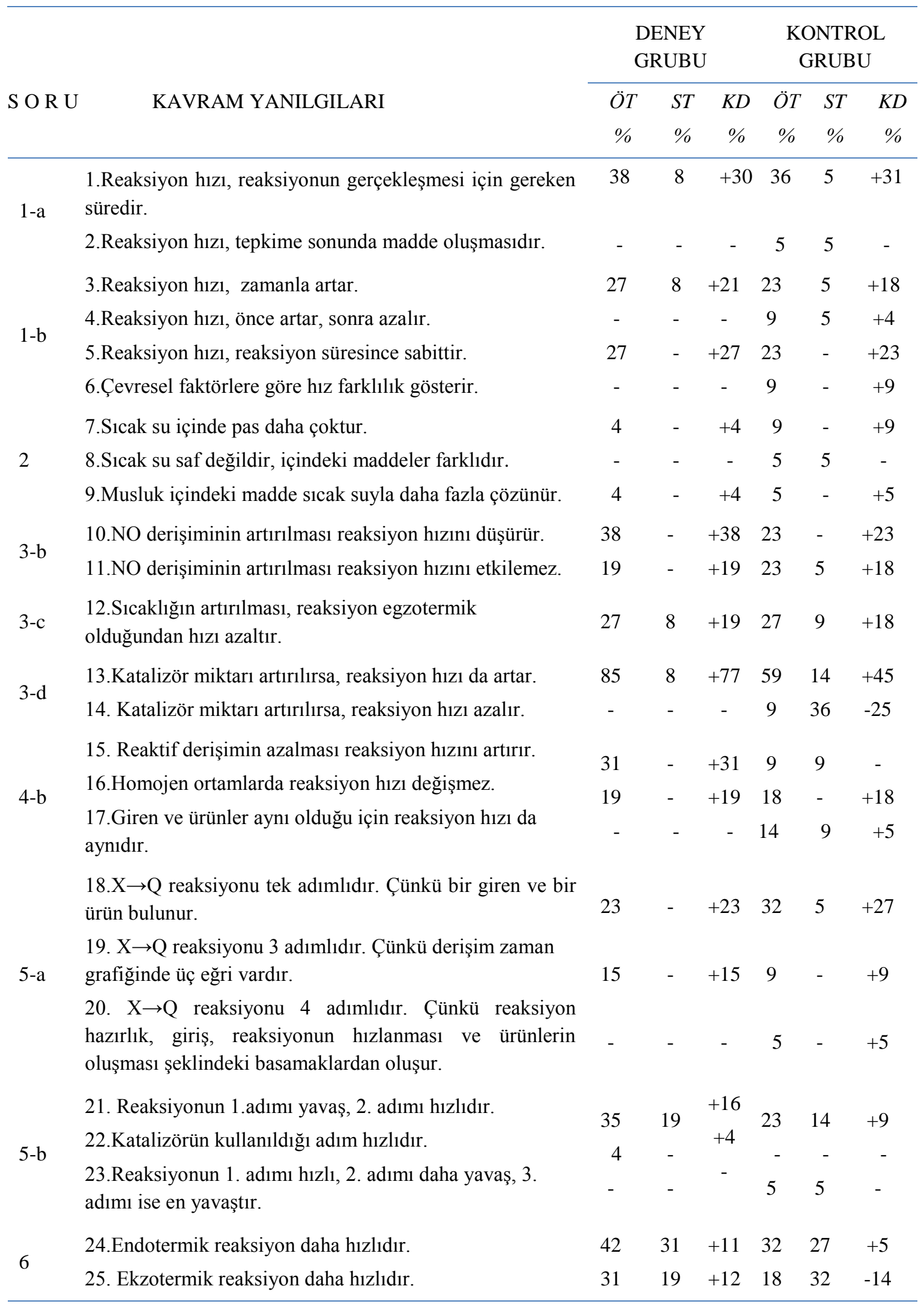


Tablo 7 Devamı

\begin{tabular}{|c|c|c|c|c|c|c|c|}
\hline \multirow[b]{2}{*}{ S O R U } & \multirow{3}{*}{ KAVRAM YANILGILARI } & \multicolumn{3}{|c|}{$\begin{array}{l}\text { DENEY } \\
\text { GRUBU }\end{array}$} & \multicolumn{3}{|c|}{$\begin{array}{c}\text { KONTROL } \\
\text { GRUBU }\end{array}$} \\
\hline & & $\ddot{O} T$ & $S T$ & $K D$ & $\ddot{O} T$ & $S T$ & $K D$ \\
\hline & & $\%$ & $\%$ & $\%$ & $\%$ & $\%$ & $\%$ \\
\hline
\end{tabular}

6 26. İki reaksiyonun hızları aynıdır. Çünkü sıcaklıkları aynidir.

$\begin{array}{llllll}8 & 4 & +4 & 5 & -\end{array}$

27. Başlangıçta iki reaksiyonun hızları aynıdır, fakat ekzotermik reaksiyon 1sı verdiği için yavaşlar, endotermik reaksiyon ise 1 sı aldığı için hızlanır.

28.Kullanılan $\mathrm{HCl}$ ve $\mathrm{MgO}$ miktarları aynı olduğu için iki tepkimenin tepkime hızları da aynıdır.

29.Aktivasyon enerjisi, reaksiyona girenlerin kinetik enerjisidir.

30.Aktivasyon enerjisi, reaksiyona girenlerin potansiyel enerjisidir.

31.Aktivasyon enerjisi, tepkimenin gerçekleşmesi için gerekli sicaklıktır.

32.Aktivasyon enerjisi, tepkimedeki toplam enerji miktarıdır.

33. Aktivasyon enerjisi fazla olan ikinci reaksiyon hızlıdır.

34. Aktivasyon enerjilerine göre reaksiyon hızlarını

8-b karşılaştırmak mümkün değildir.

35. Katalizörün reaksiyon hızına etkisi yoktur.

9-a 36 . Katalizör reaksiyon hızını azaltır.

37. Katalizör ilavesi, aktivasyon enerjisini artırır.

$9-a_{2}$

38. Katalizör ilavesi, aktivasyon enerjisini etkilemez.

39.Katalizör, oluşan ürün miktarını artırır.

9-a $\quad$ 40.Katalizör, oluşan ürün miktarını azaltır.

41.Katalizör kullanıldığında farklı ürün oluşturabilir.

42.Katalizör ilavesi, reaksiyon mekanizmasını etkilemez.

$12 \quad-\quad+12 \quad 14 \quad 5 \quad+9$

43. Katalizör ilavesi, reaksiyon mekanizmasını azaltır.

9-c 44. Katalizör ilavesi, aktivasyon enerjisini artırır.

$15 \quad-\quad+15 \quad-\quad-\quad-$

$\begin{array}{llllll}- & - & - & & & \\ - & & & \end{array}$

$27 \quad-\quad+27 \quad 18 \quad 18 \quad$ -

$4 \quad-\quad+4 \quad 32 \quad-\quad+32$

$\begin{array}{llllll}27 & 4 & +23 & 14 & 23 & -9\end{array}$

12 - +12 - -

$4 \quad-\quad+4 \quad-\quad-\quad-$

$\begin{array}{llllll}50 & 8 & +42 & 50 & 23 & +27\end{array}$

$\begin{array}{llllll}4 & - & +4 & 9 & - & +9\end{array}$

$\begin{array}{llllll}- & - & - & 9 & - & +9\end{array}$

Aynı zamanda, deney grubunda pek çok kavram yanılgısına son-testte rastlanmadığı da görülmektedir. Özellikle de bu yanılgılar incelendiğinde bunların, derişimin reaksiyon hızına etkisi $(10,11,15,16$ ve 17 . yanılgılar), aktivasyon enerjisi, 
hızlı-yavaş reaksiyonlar (33 ve 34. yanılgılar), katalizörün reaksiyon hızına etkisi (13, $35,36,37$ ve 38. yanılgılar) konularında geliştirilen örnek olayların içeriği ile ilgili olduğu görülmektedir.

Tablo 7'de ortaya konulan bulgulardan biri de kavramsal değişim yüzdesidir. Deney ve kontrol grupları için verilen kavram yanılgılarına ait kavramsal değişim yüzdesi kıyaslandığında, deney grubu için kavramsal değişim yüzdesinin pek çok durumda $(3,5,10,11,12,13,15,16,19,21,24,25,28,29,33,34,37,39,42$. yanılgılar) daha yüksek olduğu görülmektedir. Kontrol grubunda kavramsal değişim yüzdesinin daha yüksek olduğu durumlar incelendiğinde $(1,7,9,18,26,38$ ve 43. yanılgılar) ise 1. ve 26. kavram yanılgısı hariç, geri kalanlarda ön-testte kavram yanılgısı yüzdesinin kontrol grubunda daha yüksek olduğu anlaşılmaktadır. Bu iki kavram yanılgısı incelendiğinde, 1. kavram yanılgısının reaksiyon hızının tanımı ile ilgili olduğu ve geliştirilen örnek olayların içeriği ile ilgili olmadığı anlaşılmaktadır. Deney ve kontrol grubu için bu kavram yanılgısına ait kavramsal değişimde de çok büyük bir fark olmamıştır. 26. kavram yanılgısında benzer durum söz konusu olup, her iki gruptaki kavramsal değiş̧im birbirine çok yakındır. Kontrol grubuna ait kavramsal değişim yüzdelerinde ortaya çıkan önemli sonuçlardan biri de, 2, 8, 15, 23 ve 37. kavram yanılgılarında saptanmıştır. Bu kavram yanılgılarında, ön ve son-testlerde her hangi bir değişim saptanmadığından kavramsal değişim de olmamıştır. Kontrol grubuna ait kavramsal değişim yüzdelerindeki önemli bir sonuç da 14, 25, 33 ve 39. kavram yanılgılarında ortaya çıkmıştır. Bu kavram yanılgıların son-testteki yüzdesi ön-teste göre daha çok olduğunda kavramsal değişim negatif olmuştur. Benzer bulgulara, diğer araştırmalarda rastlanmış ve bu durumun nedenlerinin olarak öğrencilerin derslere aktif olarak katılmamaları ve kavram yanılgısı olan öğrencilerle diğer öğrencilerin iletişime geçmeleri olabileceği belirtilmiştir (Case ve Fraser 1999; Coştu, Ayas, Niaz, Ünal ve Çalık, 2007; Ebenezer 2001; Hewson ve Hewson, 1983).

Tablo 7'den, aynı zamanda, hem deney hem de kontrol grubunda bazı kavram yanılgılarının öğretim sonrası da mevcut olduğu anlaşılmaktadır. Bu sonuç, öğrencilerin bu kavram yanılgılarını değiştirmeye dirençli olduklarını göstermektedir. Lakatos (1970), kavram yanılgıları iyi yapılandırılmışsa, öğrencilerin bu kavram yanılgılarını, bilimsel olanlarla değiştirmeyi reddedebileceklerini ifade etmiştir. Nitekim, benzer sonuçlar literatürdeki çeşitli araştırmalarda da ortaya konulmuştur (Çalık, Kolomuç ve Karagölge, 2010; Driver, 1989; Hameed, Hackling ve Garnett, 1993; Osborne ve Freyberg, 1985; Şendur ve Toprak, 2013).

\section{Sonuç ve Tartışma}

Örnek olaya dayalı öğretimin, 11. sınıf öğrencilerinin kimyasal reaksiyonlarda hız konusundaki kavramsal algılamalarına etkisinin araştırıldığı bu araştırmada 1. alt probleme ait bulgulardan, deney ve kontrol gruplarının öğretim öncesi test puanları arasında anlamlı bir farkın olmadığı sonucuna ulaşılmıştır. Bu sonuç, örnek olaya dayalı öğretimin uygulandığı deney grubu ile kimya öğretim programını temel alan etkinliklerin uygulandığı kontrol grubunun, deneysel işlem öncesi birbirine denk olduğunu göstermektedir. 
Araştırmanın 2. alt problemine ilişkin bulgularda ise, deneysel uygulama sonrası test puanları arasında deney grubu lehine anlamlı bir farkın olduğu ortaya çıkmıştır. Bu sonuç 1şığında, örnek olaya dayalı öğretimin 11. sınıf öğrencilerinin kimyasal reaksiyonlarda hız konusundaki kavramsal gelişimlerinde, sadece kimya öğretim programını temel alan etkinliklerin uygulandığı öğretime göre daha etkili olduğu söylenebilir. Literatürdeki çeşitli çalışmalarda da örnek olaya dayalı öğretimin öğrencilerin kimya akademik başarılarını artırmada ve kavram yanılgılarının giderilmesinde etkili olduğu sonucuna varılmıştır (Şendur, 2011; Cheng,1995; Çam, 2009; Yalçınkaya ve Boz, 2014). Bu duruma, örnek olaya dayalı öğretimde kavramların gerçek yaşam örnekleri ile ilişkilendirilmesinin öğrencilerin anlamasını kolaylaştırması ve grup içi tartışmalar ile öğrencilerin kavram yanılgılarının farkına varması neden olmuş olabilir (Yalçınkaya ve Boz, 2014).

Araştırmanın bir diğer alt problemi olan 3. alt probleme ait bulgular, ön-testte her iki grupta pek çok soruda tam anlama (TA) kategorisinin \%50'nin altında olduğunu göstermektedir. Sadece bazı sorularda her iki grup için de TA kategorisinin yüzdesi $\% 50$ ve üstünde olabilmiştir. Bu sorular deney grubu için, temas yüzeyinin tepkime hızı üzerindeki etkisini inceleyen 7. soru ve aktivasyon enerjisi ile ilgili olan 8. soru olmuştur. Kontrol grubu için de derişim-zaman grafiğinin yorumlanması ile ilgili olan 3 . sorunun a maddesinde ve deney grubunda olduğu gibi 7 . soruda bu oranlar tespit edilmiştir. Bu sorulardaki TA yüzdesinin daha yüksek olmasının nedeni, öğrencilerin temas yüzeyinin hız üzerindeki etkisi ve aktivasyon enerjisi konularına ilişkin daha önceden sahip oldukları ön bilgiler olabilir. Aynı zamanda ön-testte bazı sorularda TA kategorisine giren her hangi bir cevaba hem deney hem de kontrol grubunda rastlanmamıştır (3-b, 3-c, 3-d, 4-b, 9-c gibi). Ancak son-testler incelendiğinde, her iki grupta da TA kategorisinin yüzde değerlerinin arttığı görülmüştür. Buna karşın, deney ve kontrol gruplarının TA kategorileri incelendiğinde, deney grubunda bu yüzdelerin daha yüksek olduğu görülmektedir. TA kategorisi ile ilgili dikkat çekici bir diğer nokta ise, kontrol grubunda son-testte, 9. sorunun $\mathrm{a}_{4}$ ve $\mathrm{c}$ alt maddelerinde TA kategorisine giren bir cevap yer almazken, deney grubunda böyle bir duruma rastlanmamasıdır. Bu sonuçlar, öğretim öncesi anlama düzeyleri birbirine yakın olan deney ve kontrol gruplarında, deneysel işlem sonunda benzer durumun olmadığını, TA kategorisinin deney grubunda daha yüksek oranlarda olduğunu göstermektedir.

Araştırmanın dördüncü alt problemi bağlamında deney ve kontrol gruplarında uygulanan öğretim yöntemlerinin kavramsal değişimin sağlanmasında etkisi olup olmadığı incelenmiştir. Deney ve kontrol gruplarındaki kavramsal değişim yüzdeleri karşılaştırıldığında, çoğu durumda deney grubunda bu yüzdenin daha yüksek olduğu ortaya konmuştur. Ayrıca araştırmada elde edilen önemli bulgulardan biri de 14, 25, 33 ve 39. kavram yanılgılarında, kontrol grubunda negatif yönde bir değişim olurken, deney grubunda böyle bir duruma rastlanmamasıdır. Deney grubunda saptanan kavram yanılgılarının hiç birinde negatif yönde bir kavramsal değişimin saptanması araştırmanın dikkat çeken sonuçlarından biridir. Nitekim, Çalık, Kolomuç ve Karagölge (2010), tarafından yürütülen çalışmada, kavramsal değişimin temel alındığı deney 
grubunda, "reaksiyonun mekanizması ve hızı belirleyen basamağın tayini" konularındaki kavram yanılgılarında negatif yönde bir kavramsal değişimin ortaya çıktığı saptanmıştır. Tüm bu sonuçlara bağlı olarak, deney grubunda uygulanan örnek olaya dayalı öğretimin, kavramsal değişimin sağlanmasında, çok daha başarılı olduğu sonucuna ulaşılabilir. Ancak deney grubunda geliştirilen tüm örnek olayların, kavramsal değişim üzerinde aynı etkiyi oluşturduğu tam olarak söylenemez. Örneğin, sıcaklığın ve temas yüzeyinin tepkime hızı üzerindeki etkileri ile ilgili olan kavram yanılgılarındaki $(7,8,9,12$ ve 28.) kavramsal değişim yüzdeleri her iki grupta da birbirine yakın olmuştur. Bu sonuç, aktivasyon enerjisi, hızlı- yavaş reaksiyonlar, derişim ve katalizör ile ilgili olan örnek olayların kavramsal değişim üzerinde daha etkili olduğunu göstermektedir.

\section{Öneriler}

Araştırmadan elde edilen bulgular, her ne kadar geliştirilen örnek olayların, kavramsal değişimin sağlanmasında etkili olduğunu gösterse de, temas yüzeyi ve sıcaklığın tepkime hızı üzerindeki etkisini inceleyen örnek olaylar, diğerleri kadar çok etkili olamamıştır. Bu nedenle, bu örnek olaylar tekrar değerlendirilerek, öğrencilerin anlamadıkları ya da zorlandıkları noktaların neler olduğu saptanarak, yeniden tasarlanması sağlanabilir.

Araştırmada, aktivasyon enerjisi, yavaş ve hızlı tepkimeler, tepkime hızına etki eden faktörlerle ilgili örnek olaylar geliştirilmiştir. Tepkime hızının tanımlanması ve tepkime mekanizmaları konularını da içeren örnek olaylar geliştirilerek bunların uygulamaları başka araştırmalarda da yürütülebilir.

2013 yılında revize edilen ortaöğretim kimya programın temel amaçları dikkate alındığında, bireylerin kimyanın gündelik hayattaki yerini kavramalarına ve değerini fark etmelerine yardımcı olabilecek öğretim yöntemleri önem kazanmıştır. Bundan dolayı, bu yöntemlerden biri olan örnek olaya dayalı öğretim ve bunun kimya eğitimindeki uygulamaları konularında özellikle kimya öğretmenlerine yönelik yapılacak seminerlerin olumlu etkileri olabileceği düşünülmektedir. 


\section{Kaynakça}

Abraham, M. R., Grzybowski E. B., Renner, J. W., \& Marek, E. A. (1992). Understandings and misunderstandings of eight grades of five chemistry concepts found in textbooks. Journal of Research in Science Teaching, 29(2), 105-120.

Ayyıldız, Y., \& Tarhan L. (2013). Case study applications in chemistry lesson: gases, liquids, and solids. Chemistry Education Research and Practice, 14(4), 408-420.

Brink, D., Goodney, H., Hudak, N., \& Silverstein, B. A. (1995). Novel spirit approach the introduction chemistry using case studies of chemistry in real world. Journal of Chemical Education, 72, 530-532.

Case, M. J., \& Fraser, D. M. (1999). An investigation into chemical engineering students' understanding of the mole and the use of concrete activities to promote conceptual change. International Journal of Science Education, 21, 1237-1249.

Cheng, M. (1995). An environmental chemistry curriculum using case studies. Journal of Chemical Education, 72, 25-527.

Cohen, L., Manison, L., \& Morrison, K. (2007). Research methods in education (6th Ed). New York: Taylor \& Francis Group.

Cornely, K. (1998). Use of case studies in an undergraduate biochemistry course. Journal of Chemical Education, 75, 475-478.

Coştu, B., Ayas, A., Niaz, M., Ünal, S., \& Çalık, M. (2007). Facilitating conceptual change in students' understanding of boiling concept. Journal of Science Education and Technology, 16, 524-536. doi: 10.1007/s10956-007-9079-x

Çam, A. (2009). Effectiveness of case-based learning instruction on students understanding of solubility equilibrium concepts (Yayınlanmamış doktora tezi). Ortadoğu Teknik Üniversitesi, Ankara.

Çam, A., \& Geban, Ö. (2011). Effectiveness of case-based learning instruction on epistemological beliefs and attitudes toward chemistry. Journal of Science Education and Technology, 20(1), 26-32. doi: 10.1007/s10956-010-9231-x

Çakmakçı, G. (2005). A cross-sectional study of the understanding of chemical kinetic among turkish secondary and undergraduate student (Yayınlanmamış doktora tezi). The University of Leeds, York.

Çakmakçı, G., Leach, J., \& Donnelly, J. (2006). Students' ideas about reaction rate and its realationship with concentration or pressure. International Journal of Science Education, 28(15), 1795-1815.

Çakmakçı, G. (2010). Identifying alternative conceptions of chemical kinetcs among secondary school and undergraduate students in Turkey. Journal of Chemical Education, 87(4), 449-455.

Çalık, M. (2005). A cross-age study of different perspectives in solution chemistry from junior to senior high school. International Journal of Science and Mathematics Education, 3, 671-696. 
Çalık, M., Kolomuç, A., \& Karagölge, Z. (2010). The effect of conceptual change pedagogy on students conceptions of rate of reaction. Journal of Science Education and Technology, 19, 422-433. doi: 10.1007/s10956-010-9208-9.

Çepni, S. (2007). Araştırma ve proje çalışmalarına girişs (3. Baskı). Trabzon: Celepler Matbaacilik.

Didari, V. (1986). Kömür tozu patlamalarına karş1 önlemler. Madencilik, 25(1), 9-16. "http://www.maden.org.tr/resimler/ekler/98cebccb32617ad_ek.pdf adresinden alınmıştır."

Driver, R. (1989). Students' conceptions and the learning of science. International Journal of Science Education, 11, 481-490.

Ebenezer, J. (2001). A hypermedia environment to explore and negotiate students' conceptions: animation of the solution process of table salt. Journal of Science Education and Technology, 10, 73-91.

Garnett, P. J., Garnett, P. J., \& Hackling, M. W. (1995). Students' alternative conceptions in chemistry: a review of research and implication for teaching and learning. Studies in Science Education, 25, 69-95.

Hameed, H., Hackling, M. W., \& Garnett P. J. (1993). Facilitating conceptual change in chemical equilibrium using a CAI strategy. International Journal of Science Education, 15, 221-230.

Herreid, F.C. (1994). Case studies in Science: a novel method of science education. Journal of College Science Teaching, 23, 221-229.

Hewson, M. G., \& Hewson, P. W. (1983). Effect of instruction using students' prior knowledge and conceptual change strategies on science learning. Journal of Research in Science Teaching, 20, 731-743. doi: 10.1002/tea.3660200804.

Herreid, C.F. (1998). Sorting potatoes for miss bonner: bringing order to case-study methodology through a classification scheme. Journal of College Science Teaching, 27(4), 236-239.

Herreid, C. F. (2005). Using case studies to teach Science. "Retrieved June 18, 2011 from http://www.actionbioscience.org/education/herreid.html".

Johnson, J., \& Purvis, J. (1987). Case studies: an alternative learning/teaching method in nursing. Journal of Nursing Education, 6, 118-120.

Jones, M. A. (1997). Use of a classroom jury trial to enhance students' perception of science as part of their lives. Journal of Chemical Education, 74(5), 537.

Kolomuç, A. (2009). Kimyasal reaksiyonlarda hiz ünitesinin 5e modeline göre animasyon destekli öğretimi (Yayınlanmamış doktora tezi). Atatürk Üniversitesi, Erzurum.

Kolomuç, A., \& Tekin, S. (2011). Chemistry teachers' misconceptions concerning concept of chemical reaction rate. Eurasian Journal of Physics and Chemistry Education, 3(2), 84-101. "Retrived from http://www.eurasianjournals.com lindex.php/ejpce" 
Kolomuç, A., \& Çalık, M. (2012). A comparison of chemistry teachears' and grade 11 students' alternative conceptions of rate of reaction. Journal of Baltic Science Education, 11(4), 333-346.

Kreber, C., Klampfleitner, M., McCune, V., Bayne, S., \& Knottenbelt, M. (2007). What do you mean by "authentic"? a comparative review of the literature on conceptions of authenticity in teaching. Adult Education Quarterly, 58 (1), 22-43.

Lakatos, I. (1970). Falsification and the methodology of scientific research programmes. In Lakatos I., \& Musgrave A. (eds.), Criticism and the growth of knowledge. (pp. 91-196). Cambridge: Cambridge University Press.

MEB. (2013). Ortaöğretim kimya dersi (9, 10, 11 ve 12. sinıflar) öğretim programı. Ankara.

Nakiboglu, C., Benlikaya, R., \& Kalın, S. (2002). Kimya öğretmen adaylarının "kimyasal kinetik" ile ilgili yanlış kavramalarının belirlenmesinde v-diyagramının kullanılması. 19.11.2011. tarihinde "http://www.fedu.metu.edu.tr/ufbmek5/b_kitabi/PDF/Kimya/Bildiri/t179d.pdf” adresinden alınmıştır.

Osborne, R., \& Freyberg, P. (1985). Learning in science: the implication of children's science, Auckland: Heinemann.

Özdamar, K. (2004). Paket programlar ile istatistiksel veri analizi 1 (5. Bask1). Eskişehir: Kaan Kitabevi

Payan, F., \& Ertürk, F. (2002). $\mathrm{SO}_{2}$ ve $\mathrm{NO}_{\mathrm{x}}$ kirleticilerinin 1995-1996 kış sezonunda Bursa için hava kirliliği haritalarının oluşturulması. Çev-Kor, 11(45), 14-17.

Sudzina, M. R. (1997). Case study as a constructivist pedagogy for teaching educational psychology. Educational Psychol Review, 9, 199-218.

Şendur, G. (2011).The effects of case-base learning on freshmen students' chemistry achievement. EEST Part B: Social and Educational Studies, 4(3), 1289-1302.

Şendur, G., Toprak, M. (2013). The role of conceptual change texts to improve students' understanding of alkens. Chemistry Education Research and Practice, 14, 431-449. doi: 10.1039/c3rp00019b.

Taştan-Kırık, Ö., Yalçınkaya, E., \& Boz, Y. (2010). Pre-service chemistry teachers' ideas about reaction mechanism. Journal of Turkish Science Education, 7(1), 47-60. "http://www.tused.org/internet/tused/default13.asp adresinden alınmıştır".

Ünal, S., Coştu, B., \& Ayas, A. (2010). Secondary school students' misconceptions of covalent bonding. Journal of Turkish Science Education, 7(2), 3-29. "http://www.tused.org/internet/tused/default13.asp adresinden alınmıştır".

Wassermann, S. (1994). Introduction to case method teaching: A guide to the galaxy. NewYork: Teachers College Press.

Wellingtoni, J. (2006). Secondary education: the key concepts. London: Routledge Taylor and Francis Group.

Wertheim, J., Oxlade, C., \& Stockley, C. (2011). Şekilli kimya sözlüğü (Z. Gürsoy Çev.). Ankara: Tübitak Yayınları. 
Yalçınkaya, E., Boz,Y., \& Erdur-Baker,Ö. (2012). Is case-based instruction effective in enhancing high school students' motivation toward chemistry? Science Education International, 23(2), 102-116. "Retrived from http:// www. icaseonline. net/ sei/ june2012/p1.pdf”

Yalçınkaya, E., Taştan-Kırık, Özgecan., Boz, Y., \& Yıldıran, D. (2012). Is case-based learning an effective teaching strategy to challenge students' alternative conceptions regarding chemical kinetics? Research in Science \& Technological Education, 30(2), 151-172. doi: 10.1080/02635143.2012.698605.

Yalçınkaya, E., \& Boz,Y. (2015). The effect of case-based instruction on 10th grade students' understanding of gas concepts. Chemistry Education Research and Practice, 16, 104-120. doi: 10.1039/c4rp00156g. 